Neeru Malhotra, Sunil Sahadev \& Nur Qamarina Sharom Accepted for publication in The International Journal of Human Resource Management, 14 April 2020 DOI: 10.1080/09585192.2020.1757737

\title{
Organisational justice, organisational identification and job involvement: The mediating role of psychological need satisfaction and the moderating role of person- organisation fit
}

\begin{abstract}
Drawing on self-determination theory, this study seeks to account for the influence of perceived organisational justice on employees' identification with the organisation and job. In particular, the study examines the mediating mechanism of psychological need satisfaction (PNS) in the relationship between the three forms of perceived organisational justice (procedural, distributive and interactional) and organisational identification as well as job involvement. Integrating the P-E fit literature, this study also investigates the underresearched moderating role of person-organisation $(\mathrm{P}-\mathrm{O})$ fit. Our findings demonstrate that PNS fully mediates the relationship between perceived justice and organisational identification as well as job involvement. Further, the direct effects of PNS and the indirect effects of perceived justice on both outcomes are found to be stronger when P-O fit is high. Although both distributive and interactional justice are found to influence PNS, the effect of the commonly investigated procedural justice is not found to be significant. Theoretical and practical implications of the study are discussed along with avenues for future research.
\end{abstract}

KEY WORDS: Psychological need satisfaction, justice, organisational identification, job involvement, person-organisation fit 
Neeru Malhotra, Sunil Sahadev \& Nur Qamarina Sharom Accepted for publication in The International Journal of Human Resource Management, 14 April 2020 DOI: 10.1080/09585192.2020.1757737

\section{Introduction}

Increasing globalisation, intensifying competition and rapidly changing markets have heightened environmental instability and consumer capriciousness that organisations around the world have to contend with (Straatman et al. 2017). In such circumstances of economic uncertainty, a workforce that is strongly committed to organisation's goals and is ready to put in extra effort could provide organisations with additional resources that can help guarantee their survival (Scrima et al. 2014). In this respect, research shows that employee identification plays a critical role in influencing employees' support for their organisation as well as involvement in behaviours not directly or formally forced by contracts (Fuchs, 2012). Echoing this line of thought, employees' identification with both organisation and job has been associated with a range of organisationally desired work outcomes such as lowered turnover intentions, increased job satisfaction, performance and citizenship behaviour (Brown, 1996; De Roeck et al. 2014; Newman et al. 2016; Riketta, 2005; Scrima et al. 2014).

Predictably, organisational identification defined as "the perception of oneness with or belongingness to" the organisation (Ashforth and Mael, 1989, p. 34) and job involvement, which refers to "the extent to which the individual psychologically identifies with his/her job" (Blau, 1987, p. 240) have emerged as key variables in the context of shaping employee management tasks within organisations. Identification develops when employees' beliefs about their organisation/job become self-referential or self-defining (Pratt 1998). As such, the more employees identify with an organization and its tasks, the more they are likely to internalise organization's values, goals, and norms. Employees who recognise the unity of self and organisation also accept the success or failure of the organisation as their own (Mael and Ashforth, 1992). Thus, from human resource management (HRM) perspective, identification can play a key role in both attracting and retaining employees as it links individuals to the organisation (Raghuram, 2011). 
Neeru Malhotra, Sunil Sahadev \& Nur Qamarina Sharom Accepted for publication in The International Journal of Human Resource Management, 14 April 2020 DOI: 10.1080/09585192.2020.1757737

In fact, having an identified workforce could provide organisations with a source of sustained competitive advantage as employees who identify with their job and organisation adopt more positive attitudes and behaviours at work that benefit the organisation (De Roeck et al. 2014; Scrima et al. 2014). However, managers realise that fostering employee identification is seldom an easy task. For instance, according to a recent survey conducted by PwC among a global sample of employees, only $28 \%$ of employees feel connected to their company's purpose (Blount and_Leinwand, 2019). A similar survey conducted in the UK also showed that only $35 \%$ of the employees feel motivated by organisation's core purpose (CIPD, 2017). Hence, understanding management initiatives that facilitate the achievement of employees' identification with both organisation and job is of continued interest to practitioners and researchers alike.

Prior literature points towards the importance of organisational justice because how an organisation treats its employees may have a substantial influence on their identification with their job and the organisation (Cropanzano et al. 1997; Edwards, 2009). Organisational justice provides employees with evidence about organisational trustworthiness and certainty about their status and standing in the organisation (Tyler \& Lind, 1992), which adds more meaning to their work life (Cropanzano et al. 2001). Justice perceptions have thus been associated with both organisational identification (Edwards, 2009; Fuchs and Edwards, 2012; Olkkonen and Lipponen, 2006) and job involvement (Brooke et al. 1988; Lambert et al. 2019), albeit separately in different studies. However, the relationship between justice and identification has often been challenged (e.g. Fuchs, 2012; Tyler and Blader, 2000; 2003) as it is argued that it fails to fully explain "why justice affects identification" (Olkkonen and Lipponen, 2006, p.213). Research is therefore required to examine potential mediating mechanisms to gain a better understanding of the processes by which justice influences identification (Brooke et al. 1988; Fuchs, 2012; Olkkonen and Lipponen, 2006). 
Neeru Malhotra, Sunil Sahadev \& Nur Qamarina Sharom Accepted for publication in The International Journal of Human Resource Management, 14 April 2020 DOI: 10.1080/09585192.2020.1757737

As employees care about justice to the extent that it meets some psychological needs (Cropanzano et al. 2001; Zapata-Phelan et al. 2009), psychological need satisfaction (PNS) may provide the underpinning mechanism to understand how and why justice influences employees' identification not only with the organisation but also with their job. While a few studies have explored PNS as a pathway through which justice influences employee outcomes, empirical research in this context not only remains scant (Aryee et al. 2015), but is also limited, in at least three key respects. First, the few studies that have examined the relationship between justice and PNS have either employed a narrow view whereby one or more of the justice types are omitted (e.g. Gillet et al. 2013; Olafsen et al. 2015) or overall justice is studied (e.g. Aryee et al. 2015; Mayer et al. 2008) thereby limiting our understanding of the distinct impact of the different facets of organisational justice on need satisfaction. Second, while prior literature highlights the importance of need satisfaction for identity formation (Gagne and Deci, 2005; Luyckx et al. 2009), little empirical research has been done to validate the influence of PNS on employees' identification with either their organisation (except for Gillet et al. 2013) or job. Finally, research has rarely considered the boundary conditions under which PNS will be more or less likely to be related to its outcomes, and more research in this respect has been called for (e.g. Leroy et al. 2015; Lian et al. 2012), particularly with respect to contextual influences that can facilitate or thwart individual attitudes and behaviours (Astakhova and Porter, 2015; Deci and Ryan, 2000). Drawing on self-determination theory (Deci and Ryan, 2000; SDT) and personenvironment (P-E) fit (Kristof-Brown et al. 2005) literature, this study develops and tests a conceptual framework (see fig.1) to address the above noted gaps in the literature, and makes theoretical as well as practical contributions. First, by investigating the mediating role of PNS, this study accounts for the previously demonstrated influence of organisational justice on identification (e.g. De Roeck et al. 2014; Olkkonen and Lipponen, 2006), and sheds light 
Neeru Malhotra, Sunil Sahadev \& Nur Qamarina Sharom Accepted for publication in The International Journal of Human Resource Management, 14 April 2020 DOI: 10.1080/09585192.2020.1757737

on a key underlying psychological mechanism to gain a better understanding of how and why justice perceptions encourage employees' organisational identification and job involvement. By studying employees' identification with both the organisation and job at the same time in a single study, we seek to develop a comprehensive understanding of the mediating role of need satisfaction in the justice-identification link as workplace can be an important source of multiple identity referents (Horton et al. 2014). Second, by examining P-O fit as a moderator, we aim to develop a better understanding of the contextual conditions that may regulate the effects of need satisfaction. Third, by studying the effects of the three forms of organisational justice on PNS simultaneously, our study is likely to develop a fine-grained understanding of how each domain of perceived justice matters in the satisfaction of psychological needs.

From a practical perspective, this study would help employers to understand how they may stimulate employees' identification with both the organisation and job, which may facilitate the achievement of organisationally desired work outcomes. In this respect, our study helps managers to understand how management practices that promote perceived justice may affect PNS and ultimately identification. Our study also offers managers with a deeper understanding of the contextual condition under which the mechanism of PNS is likely to be most effective for engendering employees' organisational identification and job involvement. Overall, this study provides both researchers and managers with important insights into the process by which justice influences identification.

\section{Conceptual framework and research hypotheses}

\section{Perceived organisational justice, organisational identification and job involvement}

Prior literature suggests that perceptions of organisational justice are strongly associated with higher levels of organisational identification (De Roeck et al. 2014; Olkkonen and Lipponen, 2006) as well as job involvement (Brooke et al. 1988; Lambert et al. 2019; Park and Kim, 
Neeru Malhotra, Sunil Sahadev \& Nur Qamarina Sharom Accepted for publication in The International Journal of Human Resource Management, 14 April 2020 DOI: 10.1080/09585192.2020.1757737

2006). In this respect, different theoretical perspectives are utilised to explain these

relationships. For instance, drawing on social exchange theory (SET; Blau, 1964) a stream of literature (Bell and Menguc, 2002; Cropanzano et al. 1997; Edwards, 2009; O’Driscoll and Randall, 1999) suggests that employee perceptions of fair and supportive work environment leads to social exchange relationships with the organisation such that employees reciprocate by forming psychological bond with the organisation/job, which occurs through a process of identification (Rousseau, 1998). Fairness fosters social exchange relationships as fair treatment is a manifestation of the discretionary organisational actions that are valued by employees (Cropanzano and Rupp, 2003). Another stream of research (De Roeck et al. 2014; Fuchs and Edwards, 2012; Olkkonen and Lipponen, 2006) utilising the social identity approach (Tajfel and Turner, 1979; Tyler and Blader, 2003) explains that justice influences organisational identification because justice communicates positive identity-relevant information to individuals. In particular, fair treatment communicates to employees that they are respected members within their group and that they can be proud of their membership.

While prior justice research has mainly attempted to establish a direct link between justice perceptions and both organisational identification and job involvement, findings have been mixed with some studies demonstrating a significant link (Lambert et al. 2019; Olkkonen and Lipponen, 2006) and others finding no direct relationship between most forms of justice and identification (Fuchs, 2012; Fuchs and Edwards, 2012). It is argued that little is done to understand why justice perceptions encourage identification (Olkkonen and Lipponen, 2006). In this respect, Fuchs (2012) tested a 'Coalescence Model of Organizational Identification' drawing variables from exchange-based, identity-based and justice-based explanations of organisational identification in a higher education setting, and concluded that organisational justice has the weakest explanatory effect on organisational identification (Fuchs, 2012). Consequently, research that considers "other, less extensively studied 
Neeru Malhotra, Sunil Sahadev \& Nur Qamarina Sharom Accepted for publication in The International Journal of Human Resource Management, 14 April 2020 DOI: 10.1080/09585192.2020.1757737

mechanisms" that have the potential to explain the relationship between different types of organisational justice and identification is called for (Fuchs, 2012; p.205). In this context, need satisfaction could be a useful mechanism to examine as Zapata-Phelan et al. (2009) suggested the theoretical possibility of need satisfaction underpinning the link between justice and employee outcomes because justice can satisfy the basic needs as described by SDT. However, there is paucity of research examining psychological need satisfaction in the much demonstrated justice effects (Aryee et al. 2015; Mayer et al., 2008) despite the recognition that people care about justice primarily because it helps to satisfy their needs (Cropanzano et al. 2001). In particular, while satisfaction of psychological needs is suggested to be a key underlying force in the relationship between environmental factors and job involvement (Brown, 1996) as well as organisational identification (Astakhova and Porter, 2015; Deci and Ryan, 2000; De Roeck et al. 2014), little empirical research has been done to examine the influence of PNS on employees' identification with either the organisation (except for Gillet et al. 2013) or job. Given the centrality of PNS in identity formation (Gagne and Deci, 2005; Luyckx et al. 2009) coupled with paucity of research on PNS in prior justice research, this study examined the mediating role of need satisfaction. Since PNS is clearly at the forefront and central in discussions of SDT (Gagne and Deci, 2005), which is perhaps the most well-established needs-based theory of motivation (Mayer et al. 2008), we utilise SDT as an alternative theoretical approach to account for the relationship between justice perceptions and employees' identification with both organisation and job.

\section{Self-determination theory (SDT)}

SDT is a positive psychological motivation theory based on the premise that people actively seek opportunities to satisfy their basic psychological needs that drive self-motivation and personality integration, in addition to facilitating conditions for these processes (Deci and Ryan, 2000). SDT identifies internalization and integration as types of motivation, whereby 
Neeru Malhotra, Sunil Sahadev \& Nur Qamarina Sharom Accepted for publication in The International Journal of Human Resource Management, 14 April 2020 DOI: 10.1080/09585192.2020.1757737

“internalization refers to people's 'taking in' a value or regulation, and integration refers to the further transformation of that regulation into their own so that, subsequently, it will emanate from their sense of self' (Ryan and Deci, 2000; p. 71). According to SDT, internalization stems from the satisfaction of three innate psychological needs, viz. the need for competence, which refers to succeeding at challenging tasks and attaining desired outcomes; the need for autonomy, which refers to experiencing choice and initiating one's own actions; and the need for relatedness, which refers to establishing a sense of mutual respect and reliance with others (Gagne and Deci, 2005). SDT considers needs not as individual differences in need strength or the extent to which an individual values particular needs but as universal necessities (Gagne and Deci, 2005). As per SDT, environmental influences on human attitudes and behaviours can be parsimoniously described as factors that can facilitate or thwart the basic needs (Deci and Ryan, 2000). In particular, contexts that are supportive of the three psychological needs foster greater internalization and integration than contexts that thwart satisfaction of these needs.

Following SDT, we posit the three dimensions of justice (procedural, distributive and interactional) as contextual variables that facilitate employees' need satisfaction thereby engendering their positive identification with the organisation and their job. Perceptions of justice help to meet basic psychological needs because justice signals some certainty regarding an organisation's commitment to help employees satisfy their needs in the context of work (Aryee et al. 2015). In other words, workplace justice provides the nutriments that enable employees to satisfy their basic needs. Greater satisfaction of the three basic needs would help employees in committing themselves to particular identity options and to identify with the commitments that they value and feel certain about (see Luyckx et al. 2009) as need satisfaction is critical for employees' willingness to invest themselves in tasks and work roles, and to internalise work rules, standards and other requirements that convey meaning to 
Neeru Malhotra, Sunil Sahadev \& Nur Qamarina Sharom Accepted for publication in The International Journal of Human Resource Management, 14 April 2020 DOI: 10.1080/09585192.2020.1757737

work-related activities (Gagne and Deci, 2005). On the other hand, unfair work environments that thwart the basic needs are likely to make employees feel pressurised to select an identity that may not fit their own interests (Luyckx et al. 2009). Consequently, such employees are less likely to internalize the organisation or their job as part of their personal identity as they may not see either the organisation or their job in favourable light. Thus, work environment (i.e. perceptions of justice) is postulated to influence employees' identification with job and organisation through the process of satisfying their psychological needs. We also posit P-O fit as the moderator of the effects of need satisfaction on organisational identification and job involvement. SDT postulates that elements of the social context may facilitate or thwart individual attitudes (Ryan and Deci, 2000), and perceptions of fit being one such element (Astakhova and Porter, 2015) may influence how need satisfaction translates into employees’ identification with organisation and job. A schematic representation of the relationships examined study in the study is provided in Fig.1

-Insert Fig. 1 here

Justice and Psychological Need Satisfaction (PNS)

Procedural justice is defined as the perceived fairness of the procedures used to arrive at outcome decisions and employees' influence over the outcomes (Colquitt, 2001). The relationship between procedural justice and the need for control is well described by the instrumental model (Tyler, 1987), which is analogous to Thibaut and Walker's (1975) control model (Cropanzano et al. 2001). Thibaut and Walker (1975) advance two criteria for procedural justice such as process control (the ability to voice one's views and opinions during a procedure) and decision control (ability to influence the actual outcome itself). Essentially, the control model focuses on the extent to which employees perceive control over their decisional outcomes. As such, procedural justice should satisfy their need for autonomy (Aryee et al. 2015). Procedural justice also satisfies employee's competence needs because 
Neeru Malhotra, Sunil Sahadev \& Nur Qamarina Sharom Accepted for publication in The International Journal of Human Resource Management, 14 April 2020 DOI: 10.1080/09585192.2020.1757737

when the procedures are ethical, free from bias, transparent and fair, the most qualified and competent individuals are most likely to be acknowledged (Mayer et al. 2008). Moreover, the group engagement model (Blader and Tyler, 2009; Tyler and Blader, 2000) posits that procedural justice is important because it signifies that people are valued by their managers and the organisation to which they belong, thereby satisfying their need for relatedness. Overall, this implies that procedural justice should satisfy the three psychological needs of employees. In this respect, a few studies recognise the relationship between perceived procedural justice and PNS (Gillet et al. 2013; Olafsen et al. 2015).

While research examining the relationship between distributive justice and need satisfaction remains scant (except for Olafsen et al. 2015), we posit that distributive justice also influences PNS. Distributive justice is mainly based on the equity rule (Leventhal, 1976) according to which rewards and resources need to be distributed in accordance with employee's contributions. Hence, distributive justice in terms of receiving equitably distributed rewards reinforces performance-reward contingencies, which satisfies competence needs (Aryee et al. 2015). Receiving an outcome that is consistent with one's contribution or effort also signifies control over outcomes, and thus should satisfy autonomy need (Mayer et al. 2008). Moreover, when a person receives equitable outcomes, it not only suggests that the organisation cares about him or her but also connotes one's respect and standing in the organisation, which should satisfy their need for relatedness.

While no prior study has investigated the relationship between interactional justice and PNS, Baard et al. (2004) argue that managerial behaviour (as depicted in the interactional justice) can be helpful for supporting satisfaction of one's basic needs. Interactional justice concerns managers' responsibilities for ensuring fairness in the decision-making procedures in the organisation (Folger and Bies, 1989), which includes giving adequate consideration to employee's view point, suppressing biases, providing justification for decisional outcomes, 
Neeru Malhotra, Sunil Sahadev \& Nur Qamarina Sharom Accepted for publication in The International Journal of Human Resource Management, 14 April 2020 DOI: 10.1080/09585192.2020.1757737

treating employees with dignity and respect and being truthful in all communications with the employees (see Colquitt, 2001). According to the group engagement model (Blader and Tyler, 2009; Tyler and Blader, 2000), interactional justice can satisfy the psychological need for relatedness or belonging because employees feel valued when they are treated fairly by their supervisor. Similarly, it is argued that fair interpersonal treatment by the supervisor, especially in terms of neutrality, trust and standing (Tyler, 1989), implies that an employee is considered competent by his or her supervisor (Mayer et al. 2008). Also, justification and truthfulness provided by the supervisor as regards the decision-making processes in the organisation helps employees to gain control over key decisions that directly affect them, thereby satisfying their need for autonomy.

Accordingly, the following hypotheses are proposed:

H1 a: Procedural justice positively influences PNS

H1 b: Distributive justice positively influences PNS

H1 c: Interactional justice positively influences PNS

Psychological Need Satisfaction (PNS) and Organisational Identification

As organisation constitutes an important source of an individual's identity, the social-identity approach postulates that people's experiences in the organisation are related to their organisational identification (Tajfel and Turner, 1979). Accordingly, satisfaction of psychological needs should promote social identification processes as satisfaction of psychological needs communicates positive social identity-relevant information to individuals (Tyler and Blader, 2000; 2003) that they are valued and respected members within their organisation (Gagne and Deci, 2005). When employees feel effective, autonomous and included in an organisation, it denotes the importance of their relationship with the organisation (Chiniara and Bentein, 2016), and promotes their feelings of genuine membership in the organisation (Tyler and Blader, 2003). Satisfaction of employees' 
Neeru Malhotra, Sunil Sahadev \& Nur Qamarina Sharom Accepted for publication in The International Journal of Human Resource Management, 14 April 2020 DOI: 10.1080/09585192.2020.1757737

psychological needs stimulates internalization of organisational rules and work processes by employees (Dysvik et al. 2013) as "satisfaction of the needs to be connected to others and to be effective in the social world support people's tendency to internalize the values and regulatory processes that are ambient in their world" (Gagne and Deci, 2005, p.337). Thus, when employees' psychological needs are satisfied they are likely to view their organisational membership as part of their personal identity (Gillet et al. 2013) since it is the organisation that provides the work environment through which their basic needs are satisfied. Hence, we hypothesize:

H2: PNS positively influences organisational identification Psychological Need Satisfaction (PNS) and Job Involvement Although no prior study has empirically investigated the link between PNS and job involvement, satisfaction of employees' psychological needs has been suggested to be a key underlying force in the relationship between environmental factors and job involvement (Brown, 1996). This is because need satisfaction creates autonomously motivated employees (Gagne and Deci, 2005) who find their jobs interesting and suited to expressing themselves. Thus, employees whose psychological needs are satisfied are more likely to possess the inner desire to devote more effort to their jobs (Chen and Chiu, 2009) and consequently are likely to get more engaged with their jobs. As satisfaction of psychological needs relates one's work-related behaviour more with one's personal identity and less with the potential attainment of some external reward (Leroy et al. 2015), need satisfaction determines the degree to which individuals internalize work rules, standards and non-explicit requirements of their job that makes their work-related activities more meaningful (Gagne and Deci, 2005); employees whose basic needs are satisfied are more likely to engage in their job voluntarily instead of feeling pressurised to do so (Gagne and Deci, 2005). When employees experience 
Neeru Malhotra, Sunil Sahadev \& Nur Qamarina Sharom Accepted for publication in The International Journal of Human Resource Management, 14 April 2020 DOI: 10.1080/09585192.2020.1757737

PNS, they are likely to regard their job as the centre of their self-concepts (Frone et al.1995), and psychologically identify with it. Hence, we hypothesize:

H3: PNS positively influences job involvement

\section{Mediating role of Psychological Need Satisfaction (PNS)}

Based on self-determination theory, the positive effects of perceived justice on employees' attitudes towards their job and the organisation can be explicated through the ability of perceived justice in satisfying the fundamental psychological needs of the employees. According to SDT, work environments that support the satisfaction of the three basic needs lead to positive work outcomes (Gagne and Deci, 2005). Building on this theoretical perspective, it is suggested that employees may react positively (negatively) to fair (unfair) treatment at work due to the effect of such treatment on their psychological needs (Lian et al. 2012). A set of theories in the organisational justice literature that focus on why justice matters to people, referred to as content models (Cropanzano et al., 2001), echo the insights provided by SDT into the mediating role of PNS. Specifically, the multiple needs model of justice (MNM; Cropanzano et al., 2001) suggests that people care about justice because it can help satisfy their basic needs of control, belonging, and positive self-regard, which relate to the three universal needs of autonomy, relatedness, and competence as identified by SDT (Mayer et al. 2008). Accordingly, a few studies recognise the mediating role of need satisfaction in the justice-outcome relationship. For example, Aryee et al. (2015) showed that need satisfaction fully mediates the relationship between overall justice and intrinsic motivation. Mayer et al. (2008) also examined overall justice instead of focusing on the specific facets in their study, and found need satisfaction to fully mediate the relationship between overall justice and job satisfaction. Only one study (Gillet et al. 2013) could be found in the literature that examined the mediating role of need satisfaction in the justiceidentification link. However, in this study only one facet of organisational justice, i.e. 
Neeru Malhotra, Sunil Sahadev \& Nur Qamarina Sharom Accepted for publication in The International Journal of Human Resource Management, 14 April 2020 DOI: 10.1080/09585192.2020.1757737

perceived procedural justice was considered. Moreover, only employees' identification with the organisation was studied as an outcome of perceived procedural justice; employees' identification with their job was not taken into account. Particularly, Gillet et al. (2013) found that need satisfaction fully mediates the relationship between perceived procedural justice and employee outcomes such as organisational identification, work satisfaction and job performance. In accordance with these scarce findings, it stands to reason that perceived justice (procedural distributive and interactional) boosts employees' identification with the organisation as well as their job because it has implications for the satisfaction of their basic needs. On the other hand, unfair work climates may thwart employees' feelings of belongingness, competence, and ability to control their environment, which leads employees to regress to a state of passivity, ill-being, and alienated functioning (Deci \& Ryan, 2000). Unfair work climates may cause people to withdraw psychologically and put in less effort for the betterment of the organisation because such an environment may reduce the likelihood of people meeting their own needs (Cropanzano et al. 1997). Given these arguments, the following hypotheses are proposed:

H4: PNS mediates the relationship between procedural justice and a) organisational identification and b) job involvement

H5: PNS mediates the relationship between distributive justice and a) organisational identification and b) job involvement

H6: PNS mediates the relationship between interactional justice and a) organisational identification and b) job involvement

\section{Moderating effect of $P$-O fit}

P-O fit refers to the degree of value congruence between employees and the value systems of their organisations (Chatman, 1989). According to self-determination theory, elements of the social context may facilitate or thwart individual attitudes (Ryan and Deci, 2000). As 
Neeru Malhotra, Sunil Sahadev \& Nur Qamarina Sharom Accepted for publication in The International Journal of Human Resource Management, 14 April 2020 DOI: 10.1080/09585192.2020.1757737

perceptions of P-O fit is one such key element (Astakhova and Porter, 2015), it is likely to regulate how need satisfaction translates into employees' identification with the organisation as well as job. Because "people are inherently motivated to feel connected to others in social milieu" (Deci and Ryan, 1994, p. 7), their engagement in favourite activities and the internalization of those activities into the self may depend upon how well they are matched with the organisation (Astakhova and Porter, 2015; Boon et al. 2011).

The moderating role of $\mathrm{P}-\mathrm{O}$ fit is also consistent with the premises of P-E fit theory (Pervin, 1989; Schneider, 1987) as psychological need fulfilment and value congruence represent two distinct traditions within the P-E fit paradigm (Muchinsky and Monahan, 1987). Psychological need fulfilment stems from the notion of complementary fit (see Cable and Edwards, 2004), which examines how people's attitudes are affected by the fit between what they need and the supplies in the environment (Edwards, 1991). In other words, people will experience more positive job attitudes when their needs are satisfied (Kristof-Brown et al. 2005). The second tradition draws from the concept of supplementary fit, which occurs when a person and an organisation possess similar characteristics and is exemplified by research examining value congruence between employees and organisations (Kristof, 1996). Prior research understanding the theoretical integration between the two traditions suggests that P-O fit is likely to interact with complementary fit in determining work-related attitudes (Park et al. 2011; Resick et al. 2007) as people integrate different fit-related information (Kristof-Brown et al. 2005; Yu, 2014). For instance, $\mathrm{P}-\mathrm{O}$ fit is argued to be the most salient cue for employees when taking long-term tenure decisions such as job/organisation choice decisions (Jansen and Kristof Brown, 2006), which cannot be determined only by needs (Judge and Bretz, 1992). In a similar vein, it can be argued that the interplay of need satisfaction and value congruence seem to better explain formation of identification. Since identification is a process that is based on subjective beliefs and involves the extraction of 
Neeru Malhotra, Sunil Sahadev \& Nur Qamarina Sharom Accepted for publication in The International Journal of Human Resource Management, 14 April 2020 DOI: 10.1080/09585192.2020.1757737

cues from the environment, ascertaining whether one identifies with the organisation or job is likely to entail interpretations of one's own values as well as those of the organisation (see Pratt, 1998), and may not be determined alone by need satisfaction. Employees with high P-O fit share similar motives and goals as that of the organisation (Meglino and Ravlin, 1998), have better understanding of organisational needs, priorities, rules and regulations (Edwards and Cable, 2009) and are therefore well-adjusted in the workplace (O'Reilly et al., 1991), which makes the organisation more attractive to such employees (Yu, 2014). As a result, employees with high P-O fit develop positive feelings about the organisation, which facilitates the internalization of the organisation as well as its job tasks into the self (Astakhova and Porter, 2015; Straatmann et al. 2017). As employees with high P-O fit react more positively (Kristof-Brown et al. 2005) and are likely to better respond to signals (such as PNS) that the organisation sends through its best HR practices (Boon et al. 2011), the intended effects of PNS on employees' identification with the organisation and job are likely to be greater when P-O fit is high.

In particular, we posit that while need satisfaction helps to stimulate employees' organisational identification, those who also share the values of the organisation are likely to identify with the organisation at a much greater rate as such employees view their organisational membership as a key way to define their social identity (Yu, 2014). Since employees strive for a positive self-concept, higher levels of P-O fit coupled with need satisfaction significantly enhance their perceptions of belongingness towards the organisation. In such situations when both P-O fit and PNS are high, organisational membership may positively reflect on the self, and subsequently further the positive selfconcept that is sought after by the employees (Straatmann et al. 2017; van Knippenberg \& Sleebos, 2006). Similarly, while need satisfaction enhances job involvement by making job tasks more meaningful and intrinsically enjoyable for employees (Gagne and Deci, 2005), the 
Neeru Malhotra, Sunil Sahadev \& Nur Qamarina Sharom Accepted for publication in The International Journal of Human Resource Management, 14 April 2020 DOI: 10.1080/09585192.2020.1757737

effect is likely to be much stronger among the high P-O fit cohort because such employees are willing to take initiative and show loyalty and enthusiasm for their employing organisation (Boon et al. 2011). As high P-O fit employees align their personal goals with those of the organisation (Erdogan and Bauer, 2005), they are willing to expend more effort on job tasks on behalf of the organisation (Straatmann et al. 2017). Accordingly, when their psychological needs are met, such employees are likely to get more involved with their job tasks (Blau, 1987) as compared to employees with low P-O fit.

Conversely, the effect of need satisfaction on employee outcomes may get attenuated if $\mathrm{P}-\mathrm{O}$ fit is low. Low $\mathrm{P}-\mathrm{O}$ fit creates an environment of unpredictability, uncertainty and lack of trust, which causes alienation, anxiety and impedes actions that help employees achieve what they desire (Edwards and Cable, 2009). Employees with low P-O fit may not openly communicate or relate with other members of the organisation (Erdogan and Bauer, 2005), which implies that they are unable to engage in cooperative behaviour and work towards common goals (Mayer et al. 1995). Thus, employees with low P-O fit may not be able to make sense of the organisation and their relationship to it (Ashforth et al. 2008), which may dampen the positive effects of PNS on their identification with the organisation as well as its tasks. Hence, we hypothesise:

H7: P-O fit moderates the effect of PNS on organisational identification such that the effect is stronger when $\mathrm{P}-\mathrm{O}$ fit is high rather than low

H8: P-O fit moderates the effect of PNS on job involvement such that the effect is stronger when $\mathrm{P}-\mathrm{O}$ fit is high rather than low

As we have developed theoretical underpinnings for the mediating effects of PNS in the justice -organisational identification and justice-job involvement links as well as the moderating effects of $\mathrm{P}-\mathrm{O}$ fit on the PNS-organisational identification and PNS-job involvement relationships, the theoretical rationale behind these hypotheses also suggests that 
Neeru Malhotra, Sunil Sahadev \& Nur Qamarina Sharom Accepted for publication in The International Journal of Human Resource Management, 14 April 2020 DOI: 10.1080/09585192.2020.1757737

P-O fit will influence the strength of the indirect relationships, thereby suggesting a pattern of moderated mediation. Hence, we hypothesise:

H9: P-O fit moderates the indirect effect of a) procedural justice b) distributive justice c) interactional justice on organisational identification (through PNS), such that the indirect effects are stronger when $\mathrm{P}-\mathrm{O}$ fit is high rather than low

$\mathrm{H} 10$ : $\mathrm{P}-\mathrm{O}$ fit moderates the indirect effect of a) procedural justice b) distributive justice c) interactional justice on job involvement (through PNS), such that the indirect effects are stronger when $\mathrm{P}-\mathrm{O}$ fit is high rather than low

\section{Methodology}

\section{Context and Sample}

To test the conceptual model an empirical study was conducted among the academic staff of higher educational institutions in Malaysia. One of the researchers individually contacted the HR managers to conduct the study and to facilitate data collection. Seven universities based in the state of Kuala Lumpur and Selangor were contacted as most universities are located in these two locations in Malaysia. Only academic staff were invited to participate in the study. Two institutions agreed to participate in the study. A cover letter was attached to each questionnaire thereby ensuring the participants that completing the survey was purely voluntary and that their responses were anonymous and would be treated with confidentiality. The respondents were informed that they are free to withdraw at any time and their responses will be excluded from the study. The researcher collected the questionnaires after completion on the same day or a few days later but not more than three working days. A total of 600 questionnaires were distributed, which resulted in 295 usable questionnaires. Of the respondents, about $29.8 \%$ were males and the remaining were females, $58 \%$ of the respondents were in the age group of $31-40$ years; $27.5 \%$ of the respondents were in the age 
Neeru Malhotra, Sunil Sahadev \& Nur Qamarina Sharom Accepted for publication in The International Journal of Human Resource Management, 14 April 2020 DOI: 10.1080/09585192.2020.1757737

group of 21-30 years; $12.5 \%$ of the respondents were in the age group of 41 to 50 and the remaining were above 50 . A total of $87.5 \%$ of the respondents were Malay, $4.1 \%$ were of Chinese origin and $4.7 \%$ were from Indian origin.

\section{Measures}

All the items used in the study were adopted from established scales in the literature. $P$ - $O$ fit was measured using eight items based on the value congruence approach by Cable and Edwards (2004). The congruence between employee's and the organisation's values were assessed with items such as "altruism" "relationship" etc., using a seven-point, unimportantimportant scale. Psychological need satisfaction was measured as a second order reflective construct using the scale developed by Deci et al (2001). The three first order constructs of autonomy, relatedness and competence were included under psychological need satisfaction, which was treated as the second order construct in the measurement and structural models. Autonomy (e.g. "I feel free to express my ideas and opinions in this job"), relatedness (e.g. "At work no one cares about me" (reverse scored)) and competence (e.g. "I feel competent at my job") were measured by four items each from Deci et al. (2001) using a seven-point dissatisfied-satisfied scale. Job involvement was measured using four items adopted from a scale developed by Lawler and Hall (1970) e.g. "I am very much involved personally in my work". Organisational identification was measured using six items from Mael and Ashforth's (1992) scale. As sample item: "When someone criticizes my organisation, it feels like a personal insult". The three justice dimensions were measured using scales adopted from Neihoff and Moorman (1993). Distributive justice was measured through a five-item scale and included items like: "I think that my level of pay is fair"; Procedural justice was measured through a six-item scale and comprised items like: "To make job decisions my dean collects accurate and complete information"; Interactional justice was measured through a six-item scale, including items like: "When decisions are made about my job, the dean is 
Neeru Malhotra, Sunil Sahadev \& Nur Qamarina Sharom Accepted for publication in The International Journal of Human Resource Management, 14 April 2020 DOI: 10.1080/09585192.2020.1757737

sensitive to my personal concerns". Responses on job involvement, organisational

identification and perceived justice were recorded using a seven-point disagree-agree scale.

We also measured age, gender, years of experience in their present job and their

organisational affiliation as control variables. Age was measured as five categories ranging from ' 20 to 30 ' to 'above 50'. Other control variables were recorded in terms of their actual value.

\section{Measurement model validation}

The measurement model was validated through a confirmatory factor analysis (CFA) procedure in AMOS, which showed an acceptable fit $\left(\chi^{2} / d f=1.97 ; \mathrm{CFI}=0.90 ; \mathrm{IFI}=0.90\right.$; RMSEA $=0.057)$. In this model, PNS was modelled as a second order reflective construct with the three components - autonomy, relatedness and competence - modelled as first order reflective constructs. All the observed variable loadings on their respective latent constructs were significant at $p<0.00$ and above 0.50 . All constructs demonstrated good validity as AVEs were above 0.50 , and acceptable reliability as Cronbach's alpha values were all above 0.70 (see Table 1). To test the discriminant validity we ran a series of CFA models comparing the goodness of fit values with the initial measurement model (see Table 2). None of the alternate models demonstrated better fit values as compared to the initial measurement model.

\section{Common Method Bias (CMB)}

To test the impact of CMB, first a Harman's test was conducted where all the observed variables were loaded on a single factor in a confirmatory factor analysis. The results (see Table 2) show an extremely poor fit $(\chi 2 / \mathrm{df}=3.42 ; \mathrm{CFI}=0.75 ; \mathrm{IFI}=0.75 ; \mathrm{RMSEA}=0.09)$, thereby demonstrating minimal impact of the common method factor influencing the observed variables (Podsakoff et al., 2003). Subsequently, we used a marker variable based method 
Neeru Malhotra, Sunil Sahadev \& Nur Qamarina Sharom Accepted for publication in The International Journal of Human Resource Management, 14 April 2020 DOI: 10.1080/09585192.2020.1757737

suggested by Lindell and Whitney (2001) whereby we included a four item scale measuring narcissicm as the marker variable in the measurement model and calculated inter-construct correlations. The mean correlation was 0.11 . We again partialled out the influence of the marker variable by calculating the difference in bi-variate correlations between the constructs of the study with and without the effect of CMB. The average difference was 0.006 . The interconstruct correlations calculated after partialling out the effect of CMB was therefore not much different from the unadjusted bi-variate correlations thereby suggesting that $\mathrm{CMB}$ is not a concern in this study. Moreover, CMB was unlikely to be a major concern because our study investigated a moderating effect (Evans, 1985), implying that the respondents were unable to predict or manipulate their responses related to interaction effects.

\section{Results}

The hypotheses were tested in two stages. In the first stage, the hypotheses H1 to H6 were tested through a structural equation model using AMOS. The basic model provided a good fit $\left(\chi^{2} / d f=2.01 ; \mathrm{CFI}=0.92 ; \mathrm{IFI}=0.92 ; \mathrm{RMSEA}=0.058\right)$. We also included age, gender, experience and organisation as control variables. The control variables were not found to have any significant impact. The impact of procedural justice on PNS is not found to be significant $(\beta=-0.38, \mathrm{p}>0.10)$, hence $\mathrm{H1}$ a is not supported. The effects of distributive $(\beta=$ $0.42, \mathrm{p}<0.01)$ and interactional justice $(\beta=0.66, \mathrm{p}<0.01)$ on PNS are positive and significant thus supporting $\mathrm{H} 1 \mathrm{~b}$ and $\mathrm{H} 1 \mathrm{c}$. Further the direct impact of PNS on organisational identification $(\beta=0.43, \mathrm{p}<0.01)$ and job involvement $(\beta=0.46, \mathrm{p}<0.01)$ are both positive and significant. Thus, hypotheses $\mathrm{H} 2$ and $\mathrm{H} 3$ are supported.

It is possible that procedural justice is acting as a suppressor variable in the model. If we consider the correlation coefficients (see table 1), procedural justice has a positive and significant correlation value with all the other predictor and outcome variables while having a 
Neeru Malhotra, Sunil Sahadev \& Nur Qamarina Sharom Accepted for publication in The International Journal of Human Resource Management, 14 April 2020 DOI: 10.1080/09585192.2020.1757737

negative regression coefficient with PNS. In fact, procedural justice may be considered as providing a negative suppression effect as defined by Pandey and Elliot (2010), although the negative path coefficient is not found to be significant. According to Conger (1974), a negative suppressor removes irrelevant variance from a set of predictors thereby increasing the overall predictability of the regression equation. However, as Pandey and Elliot (2010) recommends, it is always better to add a suppressor variable since omission of suppressor variables may lead to higher model error sum of squares and lower predictive power of the model. As Pedhazur (1997) suggests, adding a suppressor variable 'purifies' the outcome irrelevant variation from the independent variables thus revealing the true relationship between independent and outcome variables. Accordingly, we decided to retain procedural justice in the model.

To assess mediation effects, a boot strap procedure involving 5000 samples was employed to calculate the bias corrected confidence intervals for the indirect and direct effects. We tested mediation in structural equation modeling as this method results in lower standard errors and a greater likelihood of detecting mediation (Iacobucci, Saldanha, and Deng, 2007). Particularly, one structural model was estimated in which the direct and indirect paths were fit simultaneously. We also conducted Sobel (1982) tests to examine mediation hypotheses. The results are shown in Table 3 . The direct effects of the three justice dimensions on both organisational identification and job involvement are not found to be significant while the indirect effects of distributive and interactional justice are significant. It can thus be inferred that PNS fully mediates the relationship between distributive justice and the outcome variables as well as between interactional justice and the outcome variables. Hence H5 and H6 are supported. As the direct impact of procedural justice on PNS is not significant, H4 is not supported. 
Neeru Malhotra, Sunil Sahadev \& Nur Qamarina Sharom Accepted for publication in The International Journal of Human Resource Management, 14 April 2020 DOI: 10.1080/09585192.2020.1757737

In the second stage we tested the moderation hypotheses. P-O fit and the product term that signifies the interaction between PNS and P-O fit were introduced in the model based on the approach suggested by Ping (1995). The effect size (cohen's f ${ }^{2}$ ) increased considerably when the interaction term was introduced. For organisational identification, the effect size increased from 0.59 to 0.73 after introduction of the moderator variable. In the case of job involvement, the effect size increased from 0.13 to 0.27 after the introduction of PO-fit as the moderator. The interaction term has a positive and significant impact on both organisational identification $(\beta=0.14 ; \mathrm{p}<0.01)$ and job involvement $(\beta=0.19, \mathrm{p}<0.01)$. Hence, $\mathrm{H} 7$ and H8 are supported. The moderation graphs are plotted to show the direction of the moderation (see figures 2 and 3).

Insert Table 3 here-

-Insert fig. 2 and fig. 3 here-

\section{Moderated Mediation}

We further tested if P-O fit moderates the indirect (mediated) relationship between distributive and interactional justice and the outcome variables. The moderated mediation analysis procedure suggested by Hayes (2013) was used to assess if the statistically significant indirect effect is contingent on the value of the moderator. We used model 14 from the Hayes (2013) template to conduct the moderated mediation analysis. Based on this procedure, the mediating impact was assessed at +1 SD level of the moderator mean (high value) as well as the -1SD level of the moderator mean (low value). The boot strap procedure was run with 5000 samples. P-O fit is found to have a significant moderating effect on the indirect relationship between distributive justice and job involvement (at high value of P-O fit, $\beta=0.24$, LLCI: 0.14 , ULCI: 0.37 ; and at low value of P-O fit, $\beta=0.11$, LLCI: 0.04, ULCI: 0.19; index of moderated mediation 0.096, $\mathrm{SE}=0.032, \mathrm{p} \leq 0.01)$ and between distributive justice and organisational identification (at high value of P-O fit, $\beta=0.17$, LLCI: 
Neeru Malhotra, Sunil Sahadev \& Nur Qamarina Sharom Accepted for publication in The International Journal of Human Resource Management, 14 April 2020 DOI: 10.1080/09585192.2020.1757737

0.1, ULCI: 0.26; and at low value of P-O fit, $\beta=0.10$, LLCI: .04, ULCI: 0.17 ; index of moderated mediation $0.051, \mathrm{SE}=0.027, \mathrm{p} \leq 0.06)$. $\mathrm{P}-\mathrm{O}$ fit is also found to have a significant moderating effect on the indirect relationship between interactional justice and job involvement (at high value of P-O fit, $\beta=0.20$, LLCI: 0.10 , ULCI: 0.32 and at low value of P-O fit, $\beta=0.08$, LLCI: .01, ULCI: 0.16; index of moderated mediation $0.87, \mathrm{SE}=.033, \mathrm{p} \leq$ 0.01) and between interactional justice and organisational identification (at high value of $\mathrm{P}-\mathrm{O}$ fit, $\beta=0.16$; LLCI: 0.09, ULCI: 0.27 and at low value of P-O fit, $\beta=0.08$, LLCI: 0.01, ULCI: 0.16; index of moderated mediation $0.059, \mathrm{SE}=0.033, \mathrm{p} \leq 0.05)$. To further understand the moderated mediation effects, graphs were plotted. As can be seen in Figure 4, the positive effect of distributive justice on organisational identification through PNS is stronger for employees high in P-O fit than for those low in P-O fit. Similarly, the positive effect of distributive justice on job involvement through PNS is stronger for employees when P-O fit is high rather than low (see Figure 5). Also, Figure 6 depicts that the positive effect of interactional justice on organisational identification through PNS is stronger when P-O fit is high than low, and Figure 7 demonstrates that the positive effect of interactional justice on job involvement through PNS is stronger for employees high in P-O fit than for employees low in P-O fit. Thus, H9 (b) and (c) and H10 (b) and (c) are fully supported.

-Insert fig.4, fig.5, fig. 6 and fig. 7 here

\section{Discussion}

Although much research demonstrates a direct relationship of justice perceptions with organisational identification and job involvement (e.g. Brooke et al. 1988; Fuchs and Edwards, 2012; Olkkonen and Lipponen, 2006), findings have been largely equivocal. In this respect, more research investigating the mediating mechanisms that could explain why 
Neeru Malhotra, Sunil Sahadev \& Nur Qamarina Sharom Accepted for publication in The International Journal of Human Resource Management, 14 April 2020 DOI: 10.1080/09585192.2020.1757737

perceptions of justice translate into employees' identification with organisation and job has been repeatedly called for (Brown, 1996; Fuchs, 2012; Olkkonen and Lipponen, 2006). We respond to such calls by examining the mediating mechanism of need satisfaction to explicate how and why the three forms of justice are (un)related to these constructs as little is known about the psychological processes through which justice perceptions influence identification. While prior justice research has mainly focused on identity or social exchange processes to relate justice perceptions to identification (Colquitt et al. 2001; Fuchs, 2012), our study suggests that need satisfaction, which is grounded in SDT, is another explanatory mechanism for understanding how perceptions of justice translate into identification.

In accordance with arguments in SDT, need satisfaction is found to fully mediate the relationship between justice perceptions and organisational identification as well as job involvement. Our findings suggest that need satisfaction fully accounts for why justice relates to identification implying that need satisfaction is the means through which perceived justice influences employees' identification with the organisation as well as job. Our finding for the mediating role of PNS supports and extends existing justice research, which suggests that the mechanism of need satisfaction fully accounts for why perceived justice influences positive employee outcomes (Aryee et al. 2015; Mayer et al. 2008). As employee outcomes are conceived of as reactions by people to their environment (Salancik and Pfeffer, 1977), PNS signifies the importance of their relationship with the organisation (Chiniara and Bentein, 2016) and boosts their psychological bond with the organisation and job as unfulfilled psychological needs may lead to alienation (Brown, 1996). Our study demonstrates that it is the satisfaction of psychological needs that stimulates employees' identification not only with the organisation but also their job, which is a key finding as no empirical study has examined PNS-job involvement relationship. Thus, this study particularly contributes to research investigating the justice - identification link (e.g. Brooke et al. 1988; Fuchs, 2012; Fuchs and 
Neeru Malhotra, Sunil Sahadev \& Nur Qamarina Sharom Accepted for publication in The International Journal of Human Resource Management, 14 April 2020 DOI: 10.1080/09585192.2020.1757737

Edwards, 2012; Gillet et al. 2013; Olkkonen and Lipponen, 2006; Lambert et al. 2019) by simultaneously examining the effects of all three forms of justice on both job involvement and organisational identification via need satisfaction in the context of a singly study. Extending prior research (Fuchs, 2012) that suggests indirect effects of perceived justice on organisational identification, our study demonstrates that justice perceptions on their own substantially account for neither organisational identification nor job involvement. This study is perhaps the first that provides a comprehensive understanding of the mediating mechanism of need satisfaction, which explicates how and why different facets of perceived justice are related to employees' identification with not only the organisation but also their job.

In the context of SDT, our study demonstrates that both distributive and interactional justice are key aspects of the contextual environment that provide the nutriments for the satisfaction of basic psychological needs leading to employees' identification with their organisation and higher involvement in their jobs. In this respect, our findings underscore the utility of studying all three forms of justice simultaneously, which has remained elusive to date as all three forms of justice have not been studied simultaneously with PNS within the context of a single study. For instance, while previous studies point towards procedural justice as being important for satisfying basic needs (Gillet et al. 2013; Olafsen et al. 2015), these studies have not considered all three forms of justice. Our findings corroborate the contentions in prior literature that different forms of organisational justice can have differential effects (see Fuchs and Edwards, 2012). While distributive and interactional justice are found to influence PNS, both direct as well as indirect effects of procedural justice are not found to be significant in our study. Although there is some correlational evidence that supports individual hypothesis linking the procedural justice and PNS (Hypothesis 1a), when the structural model was tested, procedural justice does not feature in the model. Our results therefore indicate that when other forms of justice are taken into account, procedural 
Neeru Malhotra, Sunil Sahadev \& Nur Qamarina Sharom Accepted for publication in The International Journal of Human Resource Management, 14 April 2020 DOI: 10.1080/09585192.2020.1757737

justice may not necessarily be the key when considering the role that justice plays in satisfying employees' basic needs and subsequently encouraging their identification. It is likely that the importance of distributive and interactional justice in the model could explain why procedural justice does not influence need satisfaction. Possibly, as both distributive and interactional justice are directly observable, and more interpretable than procedural justice (Colquitt et al. 2013), which is relatively less clear and less "personalistic" (Barclay et al. 2005), distributive and interactional justice play a key role and draw on the theoretical mechanism between justice and need satisfaction more directly than procedural justice. Another possible explanation for this finding could be that the study is conducted in a higher education context, which is characterised by flat organisational structure, high professionalism and relatively stable environment (Erdogan and Bauer, 2005), where procedural fairness is found to be less influential than the other two forms (e.g. Bauwens et al. 2019). Our finding for the insignificant effect of procedural justice could also be due to a cultural issue as prior research testing the procedural justice- PNS relationship has been mainly conducted in western countries (e.g. Gillet et al. 2013; Olafsen et al. 2015). Employees in non-western countries are known to give more importance to the outcome and interactional forms of justice (Khan, Quratulain, and Crawshaw 2013) as immediate outcomes and interpersonal concerns are more salient for such employees than structural characteristics of the procedure. Hence, future research needs to assess the role that the three forms of justice play in the satisfaction of psychological needs as some justice types may be more important in certain contexts.

By examining the moderating role of P-O fit, our study makes another important contribution to the SDT literature as little is known about the contextual conditions that may regulate the effects of need satisfaction (Leroy et al. 2015; Lian et al. 2012). Our study demonstrates that the indirect relationship of justice to identification via need satisfaction is 
Neeru Malhotra, Sunil Sahadev \& Nur Qamarina Sharom Accepted for publication in The International Journal of Human Resource Management, 14 April 2020 DOI: 10.1080/09585192.2020.1757737

stronger among high-P-O fit individuals, as need satisfaction is more strongly related to both organisational identification and job involvement among those with high levels of P-O fit (see fig.2 and fig.3). This implies that perceptions of justice boost employees' identification through PNS, which is able to influence their identification with both organisation and job more strongly when employees have values that match those of the organisation. As employees with high P-O fit may experience greater attraction towards the organisation and its tasks that match their values and interests (Arthur et al. 2006), they react more positively to need satisfaction. This study also contributes to the extant research in the P-E fit literature as little is known about the moderating influence of P-O fit (Astakhova and Porter, 2015; Boon et al. 2011). While it is argued that examining the moderating role of $\mathrm{P}-\mathrm{O}$ fit is a fruitful area of future research (Erdogan and Bauer 2005), this has "rarely been done" (Boon et al. 2011, p. 143). As such, our study supports and extends prior research that examines P-O fit as a moderator (e.g. Astakhova and Porter, 2015; Boon et al. 2011; Erdogan and Bauer, 2005) by enhancing our understanding of novel consequences of fit. For instance, our study is perhaps the first to reveal that high $\mathrm{P}-\mathrm{O}$ fit can greatly help strengthen the indirect effects of justice and the direct effects of PNS on employees' identification with the organisation and their job. In this respect, our study accords with arguments presented in the P-E fit literature (Kristof-Brown et al. 2002; Resick et al. 2007) that employees integrate information on different types of fit. Our study provides novel insights into how the two different types of fit, i.e. value congruence and need satisfaction, work together to boost employees' identification with the organisation as well their job. As such, we also respond to calls for understanding the integration and theoretical linkages between supplementary and complementary fit (Cable and Edwards, 2004; Greguras and Diefendorff, 2009; Resick et al. 2007) as little is known about how employees integrate fit-related information (Kristof-Brown et al. 2005; Yu, 2014). In particular, our findings suggest that in order to maximise the utility of organisational 
Neeru Malhotra, Sunil Sahadev \& Nur Qamarina Sharom Accepted for publication in The International Journal of Human Resource Management, 14 April 2020 DOI: 10.1080/09585192.2020.1757737

justice mechanisms for encouraging employees' identification with the organisation and with their job, both complementary (PNS) and supplementary (P-O fit) fit are essential as both PNS and P-O fit interact to influence employees' organisational identification and job involvement.

\section{Practical Implications}

From a managerial perspective, our study provides managers with a better understanding of how organisations can elicit employees' organisational identification and job involvement through greater satisfaction of their psychological needs by enhancing employees' perceptions of organisational justice. An important implication of our study is that organisational justice stimulates employees' identification with both the organisation and their job via the mechanism of psychological need satisfaction. Thus, creating a just climate in the organisation on its own may not suffice to encourage employees' identification with either their organisation or their job. Only when perceptions of justice satisfy employees' psychological needs of autonomy, competence and relatedness, employees are motivated to better identify with their organisation and get more involved in their jobs. Enhancing employees' need satisfaction in fact should be a priority as it provides organisations with a double advantage; it stimulates employees' identification not only with the organisation but also with their job. In this respect, our findings suggest that immediate outcomes and interpersonal treatment are more salient for influencing need satisfaction. Organisational justice interventions that focus on training top management and immediate supervisors to comprehend the importance of treating employees with dignity and respect and distribution of equitable rewards may be particularly helpful in satisfying the key psychological needs of employees. Our study also provides managers with a deeper understanding of the contextual condition that regulates the effects of PNS. While organisations benefit from creating a just 
Neeru Malhotra, Sunil Sahadev \& Nur Qamarina Sharom Accepted for publication in The International Journal of Human Resource Management, 14 April 2020 DOI: 10.1080/09585192.2020.1757737

climate that satisfies employees' psychological needs, these benefits could be substantially enhanced by recruiting and retaining employees with high P-O fit. Our findings demonstrate that the indirect effects of justice and the direct effects of need satisfaction on employees' identification with the organisation and their job are likely to be much stronger for those employees who share the values of the organisation. As such, our study findings have important implications for recruitment, selection, training and other HR activities in organisations, especially hybrid organisations such as higher education institutions where the nature of work makes it difficult to manage employees within a corporate management regime, thereby making employee' work-related attitudes such as organisational identification and job involvement crucial for achieving organisational success (Fuchs, 2012; Su and Baird, 2017). For instance, university academics do complex work in an increasingly demanding environment that requires initiative, proactivity, citizenship and innovation (Grobler and van Rensburg, 2018; Houston, Meyer, and Paewai, 2006). Employees may thus find it easier to internalise organisational goals when they share their organisation's values as employees with low P-O fit may feel frustrated in their attempts to use initiative (Erdogan and Bauer, 2005), which is likely to erode their identification with the organisation as well its tasks. It may thus be prudent for organisations to recruit employees who share organisational values by carefully managing and communicating values as part of the recruitment strategy (Yu, 2014). Organisations may also explicitly communicate their core values to existing employees so these values can be easily internalised by them (Erdogan and Bauer, 2005). Training managers and immediate supervisors to use organisational socialisation practices such as company social gatherings may also be helpful in aligning the values and goals of the employees with those of the organisation (Edwards and Cable, 2009). Overall, our study suggests that both complementary and supplementary fit are crucial as both work together to influence employees' organisational identification and their job involvement, and 
Neeru Malhotra, Sunil Sahadev \& Nur Qamarina Sharom Accepted for publication in The International Journal of Human Resource Management, 14 April 2020 DOI: 10.1080/09585192.2020.1757737

subsequently help to maximise the benefits derived from creating a just and fair climate.

Enhancing satisfaction of employees' basic needs by creating a fair and supportive work environment, and aligning their values with those of the organisation through well designed recruitment and corporate communication programmes should be the focus of organisational interventions designed to improve work-based identification of employees.

\section{Limitations and Future Research}

As with any other study, this study's findings should be interpreted in the light of its limitations. This study is based on cross-sectional data and hence it is difficult to infer causality. More evidence based on longitudinal and/or experimental research is warranted. While a key finding of the study is that P-O fit regulates the effects of need satisfaction, this finding could be attributed to a cultural issue as Malaysia is a relatively collectivistic context and it is argued that collectivists emphasize fitting in with one's group (Hofstede, 1984). Moreover, teaching is primarily an autonomous, white-collar job with a high degree of professionalism (Erdogan and Bauer, 2005). Although the findings of this study are consistent with prior research in the HE context (Bauwens et al. 2019; Fuchs, 2012) and may be applicable to other professional samples, the generalisability of the study needs to be tested by replicating this study in other western cultures and in diverse occupational sectors. While this study primarily focuses on organisational identification and job involvement, future research may expand the model by incorporating behavioural outcomes such as task and contextual performance to fully comprehend the interactive effects of need satisfaction and P-O fit. It would be useful for research to consider other types of fit such as person-job fit, person-group fit and/or person-supervisor fit, which may possibly regulate the effects of need satisfaction on employees' attitudes and behaviours. 
Neeru Malhotra, Sunil Sahadev \& Nur Qamarina Sharom Accepted for publication in The International Journal of Human Resource Management, 14 April 2020 DOI: 10.1080/09585192.2020.1757737

\section{References}

Arthur, W., Jr., Bell, S. T., Villado, A. J., \& Doverspike, D. (2006), The use of personorganization fit in employment decision making: An assessment of its criterion-related validity, Journal of Applied Psychology, 91(4), 786-801

Aryee, S., Walumbwa, F. O., Mondejar, R., \& Chu, C. W. (2015), Accounting for the influence of overall justice on job performance: Integrating self-determination and social exchange theories, Journal of Management Studies, 52(2), 231-252.

Ashforth, B. E., \& Mael, F. (1989), Social identity theory and the organization, Academy of Management Review, 14(1), 20-39.

Ashforth, B. E., Harrison, S. H., \& Corley, K. G. (2008), Identification in organizations: An examination of four fundamental questions, Journal of Management, 34(3), 325-374.

Astakhova, M. N., \& Porter, G. (2015), Understanding the work passion-performance relationship: The mediating role of organizational identification and moderating role of fit at work, Human Relations, 68(8), 1315-1346.

Baard P.B., Deci E.L. \& Ryan R.M. (2004), Intrinsic need satisfaction: a motivational basis of performance and well-being in two work settings, Journal of Applied Social Psychology, 34, 2045-2068

Barclay, L. J., Skarlicki, D. P., \& Pugh, S. D. (2005), Exploring the role of emotions in injustice perceptions and retaliation, Journal of Applied Psychology, 90(4), 629-643.

Bauwens, R., Audenaert, M., Huisman, J., \& Decramer, A. (2019), Performance management fairness and burnout: implications for organizational citizenship behaviors, Studies in Higher Education, 44(3), 584-598.

Bell, S. J., \& Menguc, B. (2002), The employee-organization relationship, organizational citizenship behaviors, and superior service quality, Journal of Retailing, 78(2), 131146. 
Neeru Malhotra, Sunil Sahadev \& Nur Qamarina Sharom Accepted for publication in The International Journal of Human Resource Management, 14 April 2020 DOI: 10.1080/09585192.2020.1757737

Blader, S. L., \& Tyler, T. R. (2009), Testing and extending the group engagement model: linkages between social identity, procedural justice, economic outcomes, and extra-role behaviour, Journal of Applied Psychology, 94(2), 445-464

Blau, P. (1964). Power and exchange in social life. NY: John Wiley \& Sons.

Blau, G. J. (1987), Using a person-environment fit model to predict job involvement and organizational commitment, Journal of Vocational Behaviour, 30(3), 240-257.

Blount, S., \&_Leinwand, P (2019), Why are we here?, Harvard Business Review, NovemberDecember, 2-9.

Boon, C., Den Hartog, D. N., Boselie, P., \& Paauwe, J. (2011), The relationship between perceptions of HR practices and employee outcomes: examining the role of personorganisation and person-job fit, The International Journal of Human Resource Management, 22(01), 138-162.

Brooke, P. P., Russell, D. W., \& Price, J. L. (1988), Discriminant validation of measures of job satisfaction, job involvement, and organizational commitment, Journal of Applied Psychology, 73(2), 139-145.

Brown, S. P. (1996), A meta-analysis and review of organizational research on job involvement, Psychological Bulletin, 120(2), 235-255

Cable, D. M., \& Edwards, J. R. (2004), Complementary and supplementary fit: a theoretical and empirical integration, Journal of Applied Psychology, 89(5), 822 -834

Chatman, J. A. (1989), Improving interactional organizational research: A model of personorganization fit, Academy of Management Review, 14(3), 333-349.

Chen, C. C., \& Chiu, S. F. (2009), The mediating role of job involvement in the relationship between job characteristics and organizational citizenship behaviour, The Journal of Social Psychology, 149(4), 474-494. 
Neeru Malhotra, Sunil Sahadev \& Nur Qamarina Sharom Accepted for publication in The International Journal of Human Resource Management, 14 April 2020 DOI: 10.1080/09585192.2020.1757737

Chiniara, M., \& Bentein, K. (2016), Linking servant leadership to individual performance:

Differentiating the mediating role of autonomy, competence and relatedness need satisfaction, The Leadership Quarterly, 27(1), 124-141.

CIPD (2017), Employee Outlook 2017, available at https://www.cipd.co.uk/Images/employee-outlook_2017-spring_tcm18-21163.pdf

Colquitt, J. A. (2001), On the dimensionality of organizational justice: a construct validation of a measure, Journal of Applied Psychology, 86(3), 386-400.

Colquitt, Jason A., Donald E. Conlon, Michael J. Wesson, Christopher OLH Porter, and K. Yee Ng (2001), Justice at the millennium: A meta-analytic review of 25 years of organizational justice research, Journal of Applied Psychology, 86(3), 425-445.

Colquitt, J. A., Scott, B. A., Rodell, J. B., Long, D. M., Zapata, C. P., Conlon, D. E., and Wesson, M. J. (2013), Justice at the millennium, a decade later: A meta-analytic test of social exchange and affect-based perspectives, Journal of Applied Psychology, 98 (2),199-236.

Conger, A. J (1974), A revised definition for suppressor variables: A guide to their identification and interpretation. Educational and Psychological Measurement, 34, 3546.

Cropanzano, R., \& Rupp, D. E. (2003), An overview of organizational justice: Implications for work motivation, Motivation and Work Behavior, 7, 82-95.

Cropanzano, R., Howes, J. C., Grandey, A. A., \& Toth, P. (1997), The relationship of organizational politics and support to work behaviors, attitudes, and stress, Journal of Organizational Behavior, 18, 159-180.

Cropanzano, R., Byrne, Z. S., Bobocel, D. R. and Rupp, D. R. (2001), Moral virtues, fairness heuristics, social entities, and other denizens of organizational justice, Journal of Vocational Behaviour, 58, 164-209. 
Neeru Malhotra, Sunil Sahadev \& Nur Qamarina Sharom Accepted for publication in The International Journal of Human Resource Management, 14 April 2020 DOI: 10.1080/09585192.2020.1757737

Deci, E. L., Ryan, R. M., Gagne, M., Leone, D. R., Usunov, J., \& Kornazheva, B. P. (2001), Need satisfaction, motivation, and well-being in the work organizations of a former Eastern Bloc country, Personality and Social Psychology Bulletin, 27, 930-942

Deci, E. L., \& Ryan, R. M. (2000), The 'what' and 'why' of goal pursuits: human needs and the self-determination of behaviour, Psychological Inquiry, 11, 227-268.

De Roeck, K., Marique, G., Stinglhamber, F., \& Swaen, V. (2014), Understanding employees' responses to corporate social responsibility: mediating roles of overall justice and organisational identification, The International Journal of Human Resource Management, 25(1), 91-112.

Dysvik, A., Kuvaas, B., \& Gagné, M. (2013), An investigation of the unique, synergistic and balanced relationships between basic psychological needs and intrinsic motivation, Journal of Applied Social Psychology, 43(5), 1050-1064.

Edwards, J. R. (1991), Person-job fit: A conceptual integration, literature review, and methodological critique, John Wiley \& Sons.

Edwards, M. R. (2009), HR, perceived organisational support and organisational identification: an analysis after organisational formation, Human Resource Management Journal, 19(1), 91-115.

Edwards, J. R., \& Cable, D. M. (2009), The value of value congruence, Journal of Applied Psychology, 94(3), 654-677.

Erdogan, B., \& Bauer, T. N. (2005), Enhancing career benefits of employee proactive personality: The role of fit with jobs and organizations, Personnel Psychology, 58(4), $859-891$.

Evans, M.B. (1985), A Monte Carlo study of the effects of correlated method variance in moderated multiple regression analysis, Organizational Behaviour and Human Decision Processes, 36 ( 3), 305-323. 
Neeru Malhotra, Sunil Sahadev \& Nur Qamarina Sharom Accepted for publication in The International Journal of Human Resource Management, 14 April 2020 DOI: 10.1080/09585192.2020.1757737

Folger, R., \& Bies, R. J. (1989), Managerial responsibilities and procedural justice, Employee Responsibilities and Rights Journal, 2(2), 79-90.

Frone, M. R., Russell, M., \& Cooper, M. L. (1995), Job stressors, job involvement and employee health: A test of identity theory, Journal of Occupational and Organizational Psychology, 68(1), 1-11.

Fuchs, S. (2012), Understanding psychological bonds between individuals and organizations: The coalescence model of organizational identification, Basingstoke: Palgrave Macmillan.

Fuchs, S., \& Edwards, M. R. (2012), Predicting pro-change behaviour: The role of perceived organizational justice and organizational identification, Human Resource Management Journal, 22(1), 39-59.

Gagne, M., \& Deci, E. L. (2005), Self-determination theory and work motivation, Journal of Organizational Behaviour, 26(4), 331-362.

Gillet, N., Colombat, P., Michinov, E., Pronost, A. M., \& Fouquereau, E. (2013), Procedural justice, supervisor autonomy support, work satisfaction, organizational identification and job performance: the mediating role of need satisfaction and perceived organizational support, Journal of Advanced Nursing, 69(11), 2560-2571.

Greguras, G. J., \& Diefendorff, J. M. (2009), Different fits satisfy different needs: linking person-environment fit to employee commitment and performance using selfdetermination theory, Journal of Applied Psychology, 94(2), 465-477.

Grobler, A., \& Rensburg, M. J. V. (2018), Organisational climate, person-organisation fit and turn over intention: a generational perspective within a South African Higher Education Institution, Studies in Higher Education, 1-13.

Hayes, A. F (2013), PROCESS SPSS Macro, Computer software and manual, available at www.afhayes.com. 
Neeru Malhotra, Sunil Sahadev \& Nur Qamarina Sharom Accepted for publication in The International Journal of Human Resource Management, 14 April 2020 DOI: 10.1080/09585192.2020.1757737

Hofstede G. (1984), Culture's consequences: International differences in work-related values, Newbury Park, CA: Sage.

Horton, K. E., McClelland, C. R., \& Griffin, M. A. (2014), Defined by our hierarchy? How hierarchical positions shape our identifications and well-being at work, Human Relations, 67(10), 1167-1188.

Houston, D., Meyer, L. H., \& Paewai, S. (2006), Academic staff workloads and job satisfaction: expectations and values in academe, Journal of Higher Education Policy and Management, 28(1), 17-30.

Iacobucci, D., Saldanha, N. \& Deng, X. (2007), A meditation on mediation: Evidence that structural equations models perform better than regressions, Journal of Consumer Psychology, 17 (2), 139-153.

Jansen, K. J., \& Kristof-Brown, A. (2006), Toward a multidimensional theory of personenvironment fit, Journal of Managerial Issues, 18(2), 193-212.

Judge, T. A., \& Bretz, R. D. (1992), Effects of work values on job choice decisions, Journal of Applied Psychology, 77(3), 261-271.

Khan, A.K., Quratulain, S. and Crawshaw, J.R. (2013), The mediating role of discrete emotions in the relationship between injustice and counterproductive work behaviors: A study in Pakistan," Journal of Business and Psychology, 28(1), 49-61.

Kristof, A. L. (1996), Person-organization fit: An integrative review of its conceptualizations, measurement, and implications, Personnel Psychology, 49(1), 1-49

Kristof-Brown, A. L., Jansen, K. J., \& Colbert, A. E. (2002), A policy-capturing study of the simultaneous effects of fit with jobs, groups, and organizations, Journal of Applied Psychology, 87(5), 985-993. 
Neeru Malhotra, Sunil Sahadev \& Nur Qamarina Sharom Accepted for publication in The International Journal of Human Resource Management, 14 April 2020 DOI: 10.1080/09585192.2020.1757737

Kristof-Brown, A. L., Zimmerman, R. D., \& Johnson, E. C. (2005), Consequences of Individuals' fit at work: A meta-analysis of person-job, person-organization, persongroup, and person-supervisor fit, Personnel Psychology, 58(2), 281-342.

Lambert, E. G., Haynes, S. H., Keena, L. D., May, D., \& Leone, M. (2019), Research note: the relationship of organizational justice variables with job involvement among southern prison staff, Journal of Crime and Justice, 1-15.

Lawler, E. E., \& Hall, D. T. (1970), Relationship of job characteristics to job involvement, satisfaction, and intrinsic motivation, Journal of Applied Psychology, 54(4), 305-312.

Leroy, H., Anseel, F., Gardner, W. L., \& Sels, L. (2015), Authentic leadership, authentic followership, basic need satisfaction, and work role performance: A cross-level study. Journal of Management, 41(6), 1677-1697.

Leventhal, G. S. (1976), The distribution of rewards and resources in groups and organizations, Advances in Experimental Social Psychology, 9, 91-131.

Lian, H., Ferris, D. L., \& Brown, D. J. (2012), Does taking the good with the bad make things worse? How abusive supervision and leader-member exchange interact to impact need satisfaction and organizational deviance, Organizational Behaviour and Human Decision Processes, 117(1), 41-52.

Luyckx, K., Vansteenkiste, M., Goossens, L., \&Duriez, B. (2009), Basic need satisfaction and identity formation: Bridging self-determination theory and process-oriented identity research, Journal of Counseling Psychology, 56(2), 276 - 288

Mael, F., \& Ashforth, B. E. (1992), Alumni and their alma mater: A partial test of the reformulated model of organizational identification, Journal of Organizational Behaviour, 13(2), 103-123.

Mayer, R. C., Davis, J. H., \& Schoorman, F. D. (1995), An integrative model of organizational trust, Academy of Management Review, 20(3), 709-734. 
Neeru Malhotra, Sunil Sahadev \& Nur Qamarina Sharom Accepted for publication in The International Journal of Human Resource Management, 14 April 2020 DOI: 10.1080/09585192.2020.1757737

Mayer, D. M., Bardes, M., \& Piccolo, R. F. (2008), Do servant-leaders help satisfy follower needs? An organizational justice perspective, European Journal of Work and Organizational Psychology, 17(2), 180-197.

Meglino, B. M., \& Ravlin, E. C. (1998), Individual values in organizations: Concepts, controversies, and research, Journal of Management, 24(3), 351-389.

Muchinsky, P. M., \& Monahan, C. J. (1987), What is person-environment congruence? Supplementary versus complementary models of fit, Journal of Vocational Behavior, $31(3), 268-277$.

Newman, A., Miao, Q., Hofman, P. S., \& Zhu, C. J. (2016). The impact of socially responsible human resource management on employees' organizational citizenship behaviour: the mediating role of organizational identification. The International Journal of Human Resource Management, 27(4), 440-455.

Olafsen, A. H., Halvari, H., Forest, J. \& Deci, E. L. (2015), Show them the money? The role of pay, managerial need support, and justice in a self-determination theory model of intrinsic work motivation, Scandinavian Journal of Psychology, 56, 447-457.

Olkkonen, M. E., \& Lipponen, J. (2006), Relationships between organizational justice, identification with organization and work unit, and group-related outcomes, Organizational Behaviour and Human Decision Processes, 100(2), 202-215.

O'Driscoll, M. P., \& Randall, D. M. (1999), Perceived organisational support, satisfaction with rewards, and employee job involvement and organisational commitment, Applied Psychology, 48(2), 197-209.

O’Reilly III C.A, Chatman J. \& Caldwell D.F. (1991), People and organizational culture: A profile comparison approach to assessing person-organization fit, The Academy of Management Journal, 34(3): 487-516. 
Neeru Malhotra, Sunil Sahadev \& Nur Qamarina Sharom Accepted for publication in The International Journal of Human Resource Management, 14 April 2020 DOI: 10.1080/09585192.2020.1757737

Pandey, S., \& Elliott, W. (2010), Suppressor variables in social work research: Ways to identify in multiple regression models, Journal of the Society for Social Work and Research, 1, 28-40.

Park, Y. B., \& Kim, M. S. (2006), The influence of organizational justice on job involvement and organizational commitment perceived by nurses, Journal of Korean Academy of Nursing Administration, 12(1), 32-40.

Park, H. I., Monnot, M. J., Jacob, A. C., \& Wagner, S. H. (2011), Moderators of the relationship between person-job fit and subjective well-being among Asian employees, International Journal of Stress Management, 18(1), 67-87.

Pedhazur, E. J. (1997), Multiple regression in Behavioural Research: An Explanation and Prediction. New York, NY: Holt, Rinehart \& Winston.

Pervin, L. A. (1989), Persons, situations, interactions: The history of a controversy and a discussion of theoretical models, Academy of Management Review, 14(3), 350-360.

Ping Jr, R. A. (1995), A parsimonious estimating technique for interaction and quadratic latent variables, Journal of Marketing Research, 32(3), 336-347.

Pratt, M. G. (1998), To be or not to be? Central questions in organizational identification, In D. A. Whetten \& P. C. Godfrey (eds.) Identity in organizations: building theory through conversations (171-207), Thousand Oaks, CA: Sage Publications, Inc.

Raghuram, S. (2011), Organizational identification among young software professionals in India, The International Journal of Human Resource Management, 22(18), 3913-3928.

Resick, C. J., Baltes, B. B., \& Shantz, C. W. (2007), Person-organization fit and work-related attitudes and decisions: Examining interactive effects with job fit and conscientiousness, Journal of Applied Psychology, 92(5), 1446-1455.

Riketta, M. (2005), Organizational identification: A meta-analysis. Journal of Vocational Behaviour, 66(2), 358-384. 
Neeru Malhotra, Sunil Sahadev \& Nur Qamarina Sharom Accepted for publication in The International Journal of Human Resource Management, 14 April 2020 DOI: 10.1080/09585192.2020.1757737

Rousseau, D. M. (1998), Why workers still identify with organizations, Journal of Organizational Behavior, 19, 217-233.

Ryan R.M. and Deci E.L (2000), Self-determination theory and the facilitation of intrinsic motivation, social development, and well-being, American Psychologist, 55(1): 68-78

Salancik, G. R., and Pfeffer, J. (1977), An examination of need-satisfaction models of job attitudes, Administrative Science Quarterly, 427-456.

Schneider, B. (1987), The people make the place, Personnel Psychology, 40(3), 437-453.

Scrima, F., Lorito, L., Parry, E., \& Falgares, G. (2014). The mediating role of work engagement on the relationship between job involvement and affective commitment. The International Journal of Human Resource Management, 25(15), 2159-2173.

Straatmann, T., Königschulte, S., Hattrup, K., \& Hamborg, K. C. (2017), Analysing mediating effects underlying the relationships between $\mathrm{P}-\mathrm{O}$ fit, $\mathrm{P}-\mathrm{J}$ fit, and organisational commitment, The International Journal of Human Resource Management, 1-27.

Sobel, M. E. (1982), Asymptotic confidence intervals for indirect effects in structural equation modeling, in Sociological Methodology, S. Leinhart, ed. San Francisco: Jossey-Bass, 290-312.

Su, S., \& Baird, K. (2017). The impact of collegiality amongst Australian accounting academics on work-related attitudes and academic performance. Studies in Higher Education, 42(3), 411-427.

Thibaut, J. W., \& Walker, L. (1975), Procedural justice: A psychological analysis, L. Erlbaum Associates.

Tajfel, H. \& Turner, J.C. (1979), An integrative theory of intergroup conflict, The Social Psychology of Intergroup Relations, 33-47 
Neeru Malhotra, Sunil Sahadev \& Nur Qamarina Sharom Accepted for publication in The International Journal of Human Resource Management, 14 April 2020 DOI: 10.1080/09585192.2020.1757737

Tyler, T. R. (1987), Conditions leading to value-expressive effects in judgments of procedural justice: A test of four models, Journal of Personality and Social Psychology, 52(2), 333-344.

Tyler, T. R. (1989), The psychology of procedural justice: A test of the group-value model, Journal of Personality and Social Psychology, 57(5), 830-838.

Tyler, T. R., \& Blader, S.L. (2000), Cooperation in groups: Procedural justice, social identity, and behavioural engagement, Psychology Press.

Tyler, T. R., \& Blader, S.L. (2003), The group engagement model: Procedural justice, social identity, and cooperative behaviour, Personality and Social Psychology Review, 7(4), 349-361.

Tyler, T. R., \& Lind, E. A. (1992), A relational model of authority in groups, In Advances in experimental social psychology (Vol. 25, pp. 115-191), Academic Press.

van Knippenberg, D., \& Sleebos, E. (2006), Organizational identification versus organizational commitment: Self-definition, social exchange, and job attitudes, Journal of Organizational Behavior, 27(5), 571-584.

Yu, K. Y. T. (2014), Person-organization fit effects on organizational attraction: A test of an expectations-based model, Organizational Behaviour and Human Decision Processes, 124(1), 75-94.

Zapata-Phelan, C. P., Colquitt, J. A., Scott, B. A., \& Livingston, B. (2009), Procedural justice, interactional justice, and task performance: The mediating role of intrinsic motivation, Organizational Behaviour and Human Decision Processes, 108(1), 93-105. 
Neeru Malhotra, Sunil Sahadev \& Nur Qamarina Sharom Accepted for publication in The International Journal of Human Resource Management, 14 April 2020 DOI: 10.1080/09585192.2020.1757737

Fig. 1 : Conceptual Framework

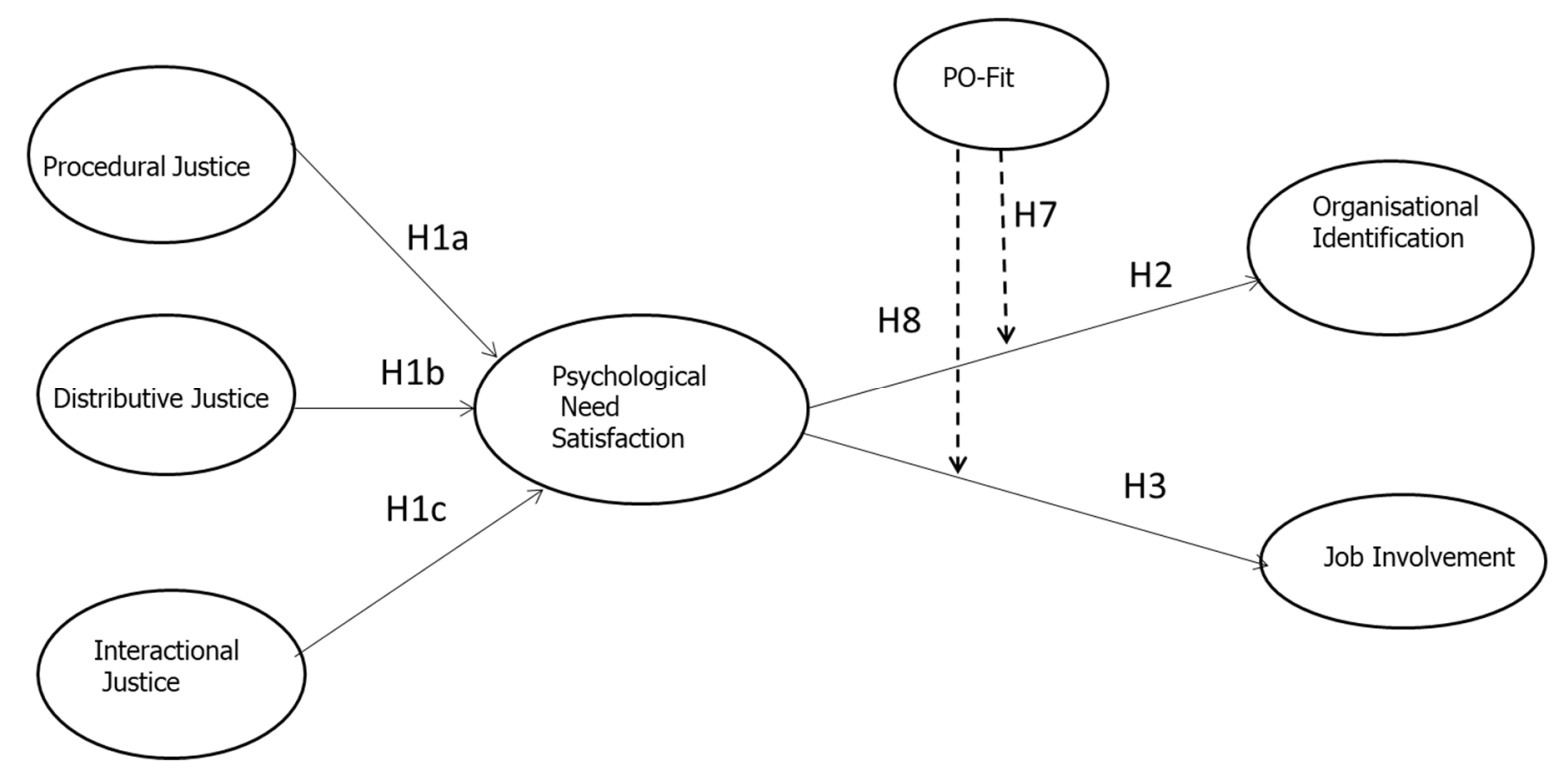


Neeru Malhotra, Sunil Sahadev \& Nur Qamarina Sharom Accepted for publication in The International Journal of Human Resource Management, 14 April 2020 DOI: 10.1080/09585192.2020.1757737

Fig.2. Moderating effect of P-O fit on the PNS-Organizational Identification Relationship

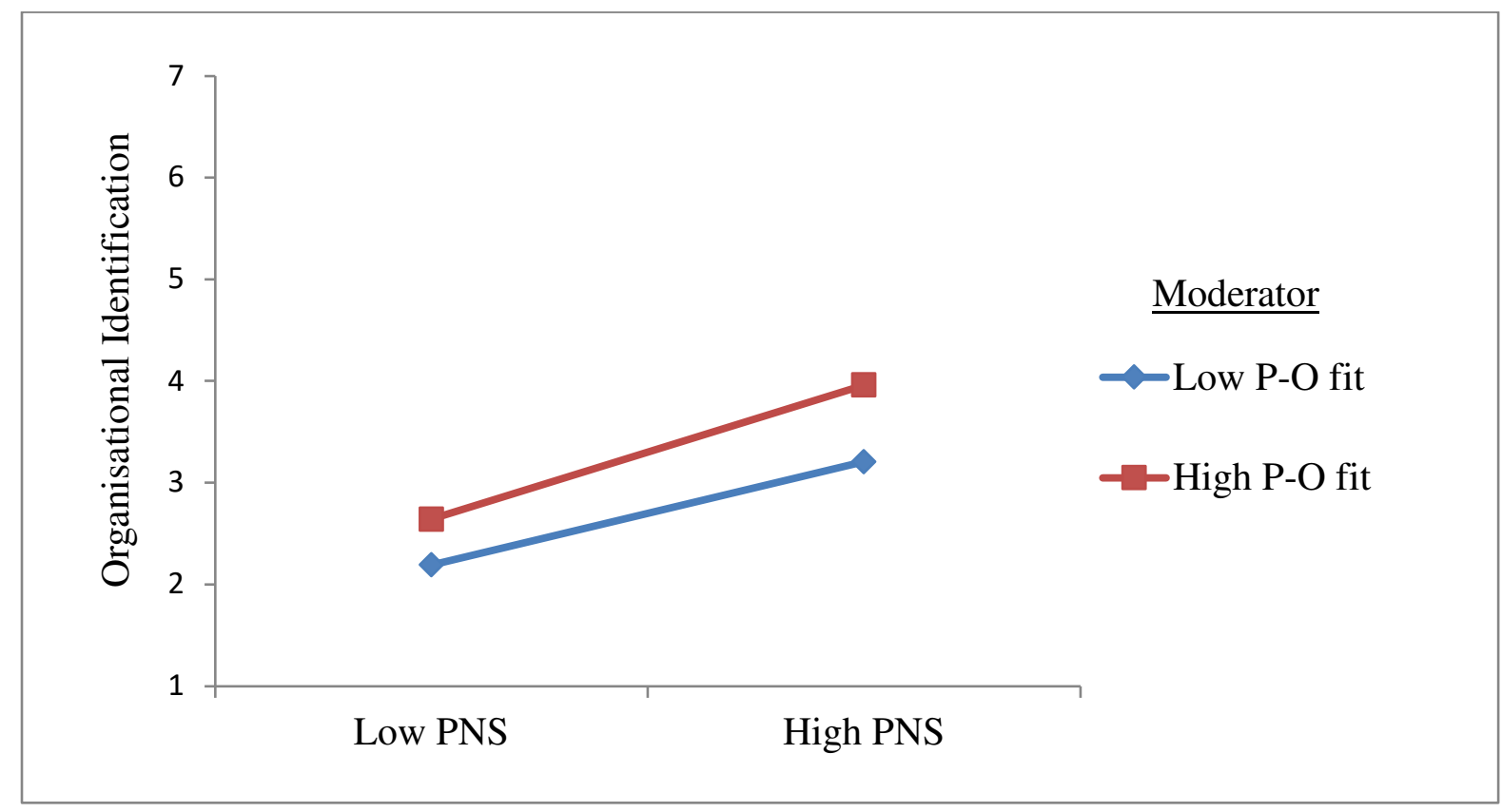

Fig.3 Moderating effect of P-O fit on the PNS-Job involvement relationship

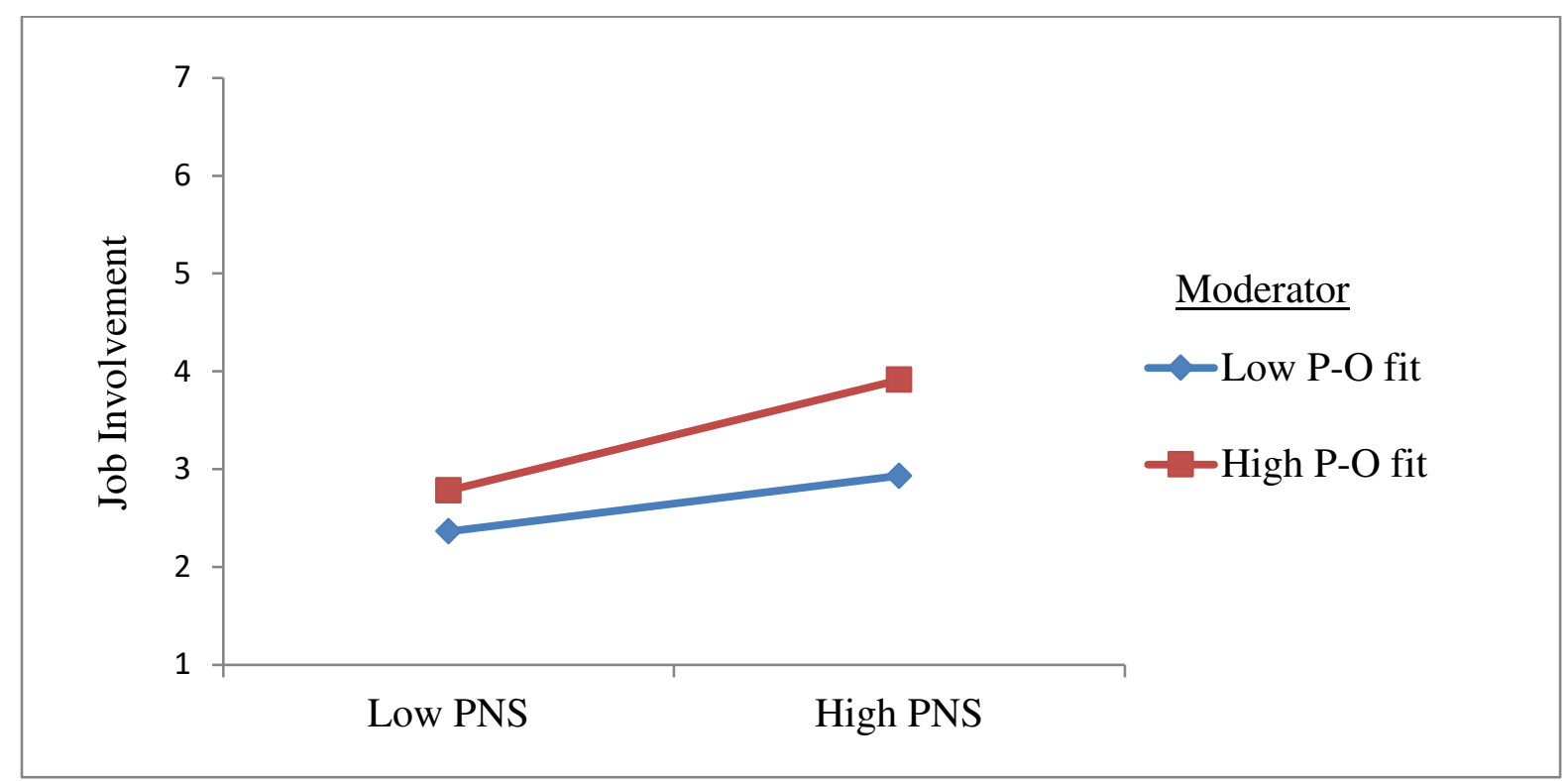


Neeru Malhotra, Sunil Sahadev \& Nur Qamarina Sharom Accepted for publication in The International Journal of Human Resource Management, 14 April 2020 DOI: 10.1080/09585192.2020.1757737

Fig.4 Conditional indirect effect of distributive justice on organisational identification through PNS, conditioned on the moderator (P-O fit), with 95\% confidence bands.

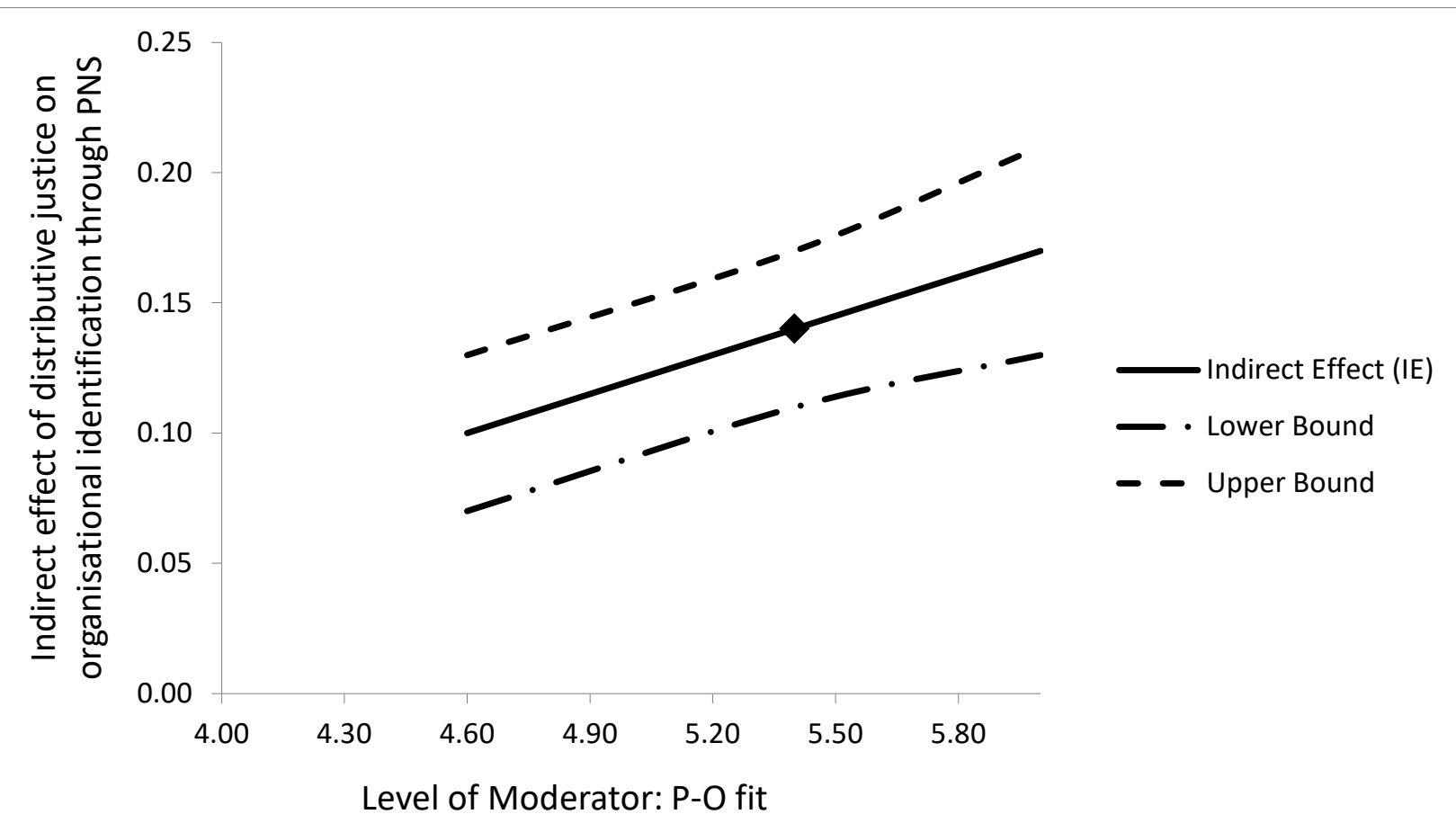

Note: The square indicates the mean level of the P-O fit. $\mathrm{CI}=$ confidence interval.

Fig.5: Conditional indirect effect of distributive justice on job involvement through PNS, conditioned on the moderator (P-O fit), with $95 \%$ confidence bands.

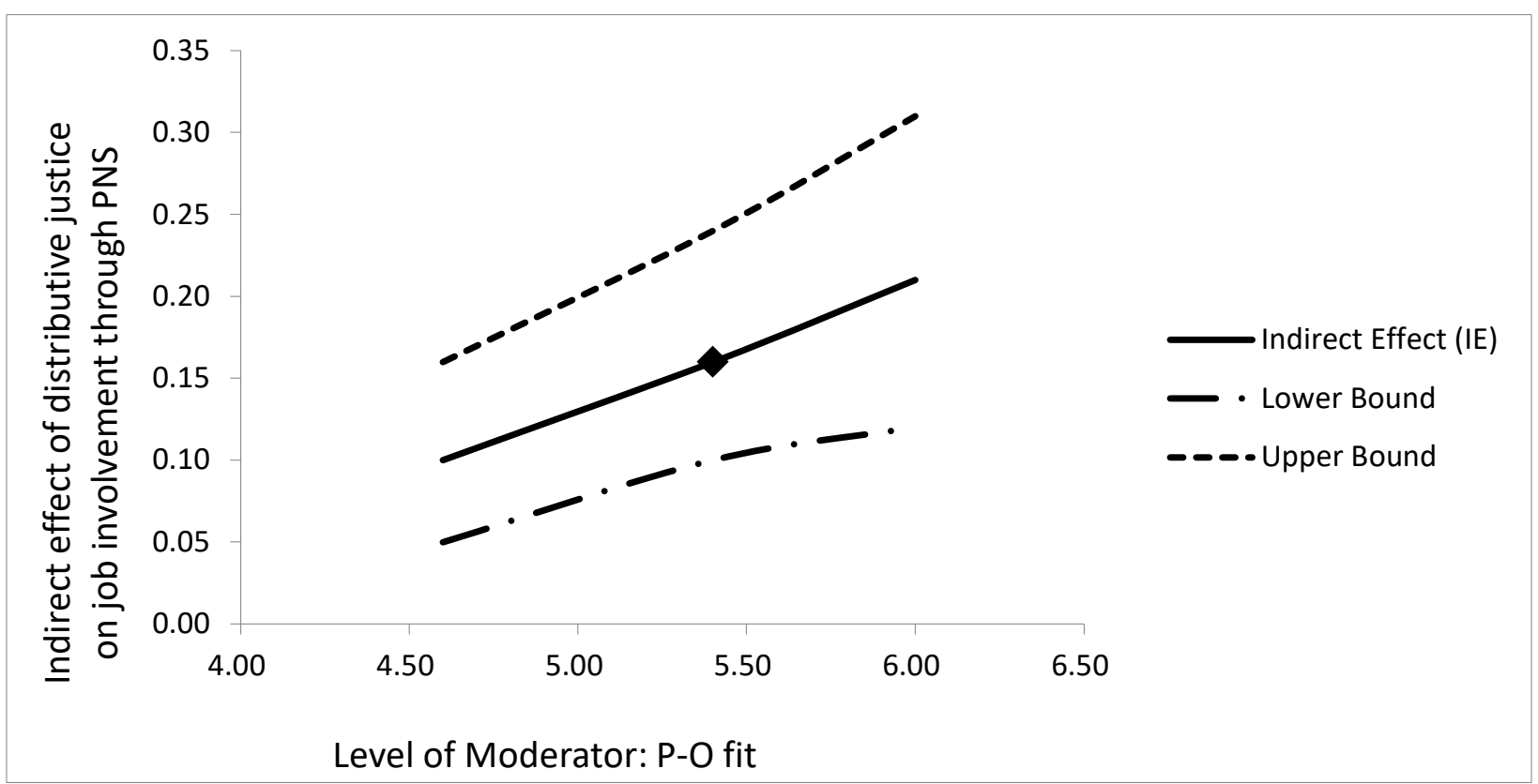

Note: The square indicates the mean level of the P-O fit. $\mathrm{CI}=$ confidence interval. 
Neeru Malhotra, Sunil Sahadev \& Nur Qamarina Sharom Accepted for publication in The International Journal of Human Resource Management, 14 April 2020 DOI: 10.1080/09585192.2020.1757737

Fig.6: Conditional indirect effect of interactional justice on organisational identification through PNS, conditioned on the moderator (P-O fit), with 95\% confidence bands.

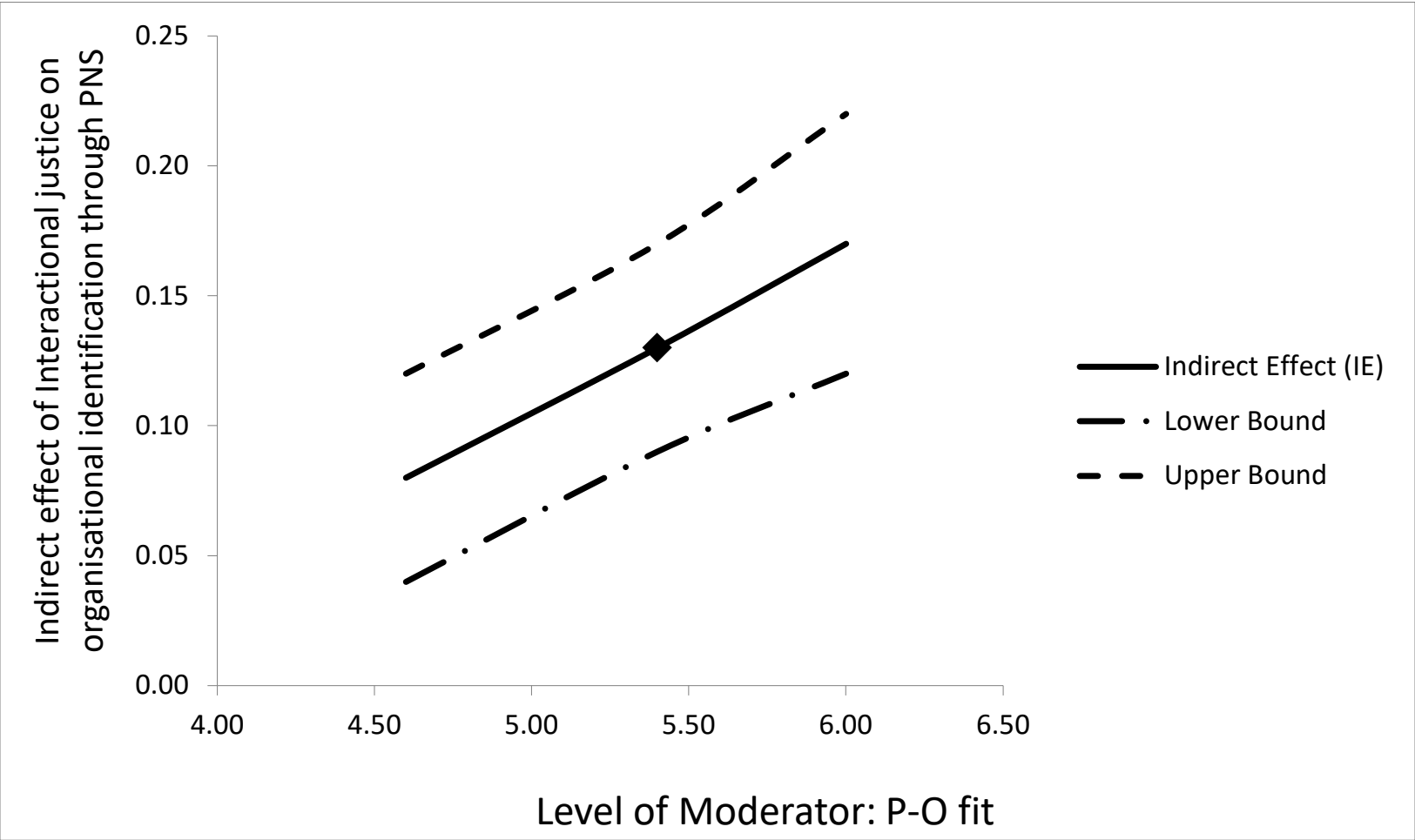

Note: The square indicates the mean level of the P-O fit. $\mathrm{CI}=$ confidence interval. 
Neeru Malhotra, Sunil Sahadev \& Nur Qamarina Sharom Accepted for publication in The International Journal of Human Resource Management, 14 April 2020 DOI: 10.1080/09585192.2020.1757737

Fig.7: Conditional indirect effect of interactional justice on job involvement through PNS, conditioned on the moderator (P-O fit), with $95 \%$ confidence bands.

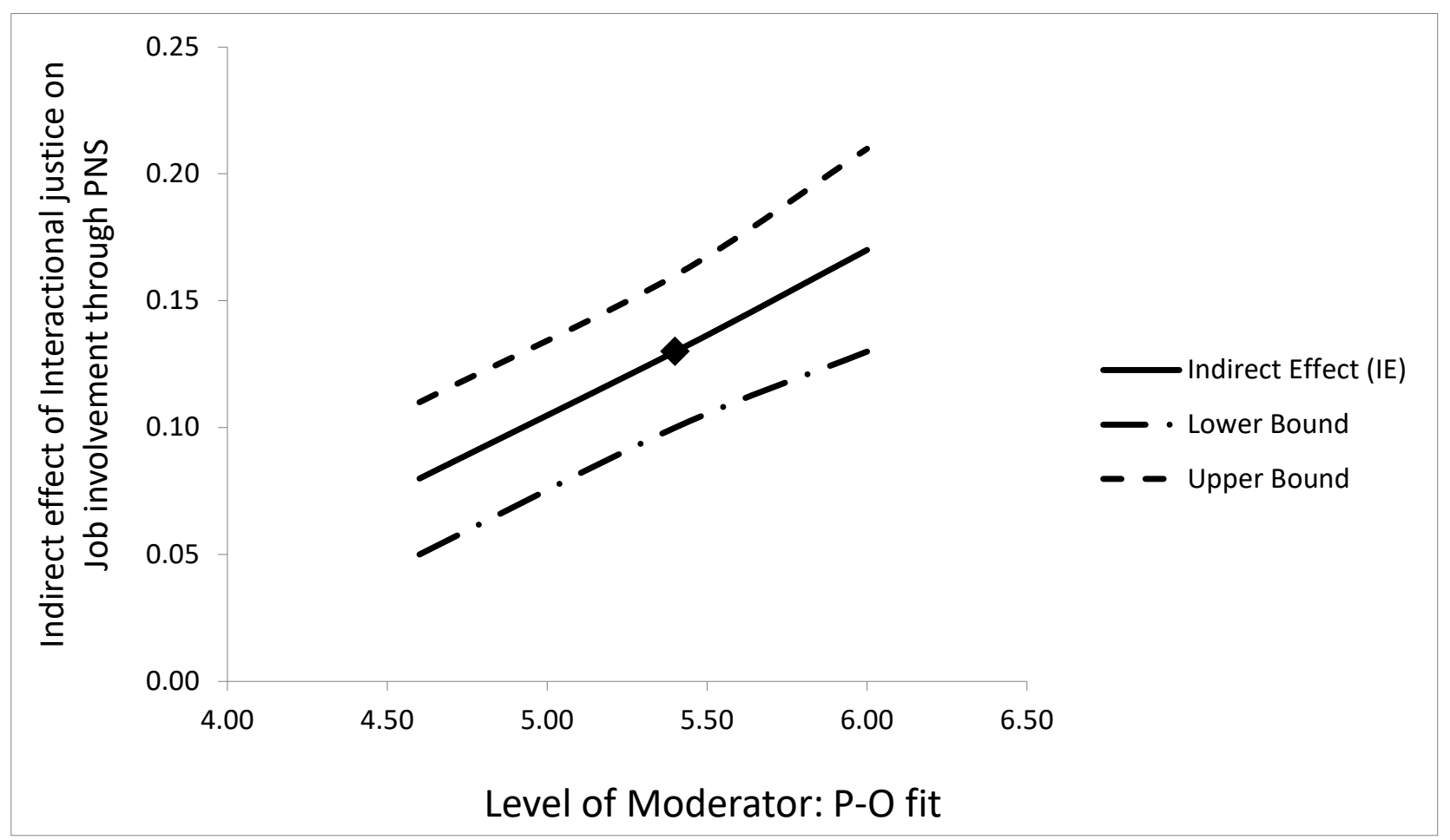

Note: The square indicates the mean level of the P-O fit. CI = confidence interval 
Neeru Malhotra, Sunil Sahadev \& Nur Qamarina Sharom Accepted for publication in The International Journal of Human Resource Management, 14 April 2020 DOI: 10.1080/09585192.2020.1757737

Table 1 Correlations, descriptives, reliability values and convergent validity statistics

\begin{tabular}{|c|c|c|c|c|c|c|c|c|c|c|c|c|c|c|}
\hline & 1 & 2 & 3 & 4 & 5 & 6 & 7 & 8 & 9 & 10 & $\mathrm{CA}$ & AVE & Mean & S. D \\
\hline 1.PNS & & $0.24 * *$ & $0.31 * *$ & $0.46 * *$ & $0.45 * *$ & $0.37 * *$ & $0.42 * *$ & $-0.16^{* *}$ & 0.07 & 0.09 & 0.87 & 0.72 & 5.41 & 0.69 \\
\hline 2.P-O Fit & & & $0.12 *$ & $0.26 * *$ & $0.25 * *$ & $0.24 * *$ & $0.16 * *$ & 0.01 & 0.01 & 0.09 & 0.90 & 0.52 & 5.39 & 0.79 \\
\hline 3.Job Involvement & & & & $0.24 * *$ & 0.06 & $0.10 *$ & $0.15^{*}$ & $-0.11 *$ & 0.05 & $0.17 * *$ & 0.83 & 0.54 & 4.60 & 1.13 \\
\hline $\begin{array}{l}\text { 4.Organizational } \\
\text { Identification }\end{array}$ & & & & & $0.34 * *$ & $0.36^{* *}$ & $0.38 * *$ & -0.05 & 0.06 & 0.04 & 0.85 & 0.50 & 5.38 & 0.86 \\
\hline 5.Distributive Justice & & & & & & $0.47 * *$ & $0.40 * *$ & $-0.13^{*}$ & $0.15^{*}$ & 0.09 & 0.86 & 0.64 & 5.07 & 1.03 \\
\hline 6.Procedural Justice & & & & & & & $0.83 * *$ & $-0.12 *$ & -0.02 & 0.03 & 0.91 & 0.61 & 4.98 & 1.05 \\
\hline 7.Interactional Justice & & & & & & & & -0.06 & -0.04 & 0.02 & 0.96 & 0.76 & 5.24 & 0.96 \\
\hline 8.Gender & & & & & & & & & $-0.19 * *$ & 0.02 & & & & \\
\hline 9.Age & & & & & & & & & & $0.37 * *$ & & & & \\
\hline 10.Experience & & & & & & & & & & & & & & \\
\hline
\end{tabular}

$* * \mathrm{p}<0.01 ;{ }^{*} \mathrm{p}<0.05, \mathrm{CA}$ - Cronbach's alpha, AVE - Average variance extracted, S.D - Standard deviation. 
Table 2: Fit statistics from measurement model comparison

\begin{tabular}{|l|l|l|l|l|}
\hline Model Specification & $\chi^{2} / d . f$ & CFI & IFI & RMSEA \\
\hline Initial measurement model with seven latent constructs & 1.97 & 0.90 & 0.90 & 0.057 \\
\hline Model 1 & 2.09 & 0.89 & 0.89 & 0.061 \\
\hline Model 2 & 2.12 & 0.88 & 0.88 & 0.063 \\
\hline Model 3 & 2.60 & 0.83 & 0.83 & 0.074 \\
\hline Model 4 & 3.00 & 0.79 & 0.80 & 0.083 \\
\hline Model 5 & 3.04 & 0.79 & 0.79 & 0.083 \\
\hline Model 6 & 3.42 & 0.75 & 0.75 & 0.091 \\
\hline
\end{tabular}

Model 1: P-O fit and Job involvement items as single factor and the other five constructs remain as in the initial model

Model 2: P-O fit, Job involvement and Organisation identification items as single factor and the other four constructs remain as in the initial model

Model 3: P-O fit, Job involvement, Organisational identification and Distributive justice as single factor and the other three constructs remain as in the initial model

Model 4: P-O fit, Job involvement, Organisational identification, Distributive justice and Procedural justice items as single factor and the other two constructs remain as in the initial model

Model 5: P-O fit, Job involvement, Organisational identification, Distributive justice, Procedural justice and Interactional justice as single factor and the remaining one construct loading as in the initial model.

Model 6: All the items loading on one single latent construct

$\chi^{2}$ - chi-square; $d . f$. - degrees of freedom; IFI- incremental fit index; CFI- comparative fit index; RMSEA- root mean square error of approximation 
Neeru Malhotra, Sunil Sahadev \& Nur Qamarina Sharom Accepted for publication in The International Journal of Human Resource Management, 14 April 2020 DOI: $10.1080 / 09585192.2020 .1757737$

Table 3: Results from the Mediation analysis (Bootstrapping - 5000 sample)

\begin{tabular}{|c|c|c|c|c|c|}
\hline & Coefficient & LLCI & ULCI & $\begin{array}{c}\text { Sobel's test } \\
\text { coefficient }\end{array}$ & Hypotheses \\
\hline Procedural Justice $\rightarrow$ Psychological Need Satisfaction & -0.29 & -1.16 & 0.16 & \multirow{4}{*}{-1.31} & \multirow{4}{*}{$\mathrm{H} 4 \mathrm{a}$} \\
\hline Psychological Need Satisfaction $\rightarrow$ Organisational Identification & $.47 * *$ & .23 & 0.78 & & \\
\hline Procedural Justice $\rightarrow$ Organisational Identification (direct effect) & 0.01 & -0.92 & 0.53 & & \\
\hline Procedural Justice $\rightarrow$ Organisational Identification (indirect effect) & -0.14 & -0.67 & 0.06 & & \\
\hline Procedural Justice $\rightarrow$ Psychological Need Satisfaction & -0.29 & -1.16 & 0.16 & \multirow{4}{*}{-1.32} & \multirow{4}{*}{$\mathrm{H} 4 \mathrm{~b}$} \\
\hline Psychological Need Satisfaction $\rightarrow$ Job involvement & $.65^{* *}$ & .31 & 1.17 & & \\
\hline Procedural Justice $\rightarrow$ Job involvement (direct effect) & -0.29 & -1.57 & 0.57 & & \\
\hline Procedural Justice $\rightarrow$ Job involvement (indirect effect) & -0.19 & -0.98 & 0.05 & & \\
\hline Distributive Justice $\rightarrow$ Psychological Need Satisfaction & $.30^{* * *}$ & .170 & 0.60 & \multirow{4}{*}{$3.06 * *$} & \multirow{4}{*}{ H5a } \\
\hline Psychological Need Satisfaction $\rightarrow$ Organisational Identification & $.47 * *$ & .23 & 0.78 & & \\
\hline Distributive Justice $\rightarrow$ Organisational identification (direct effect) & 0.04 & -0.14 & 0.27 & & \\
\hline Distributive Justice $\rightarrow$ Organisational identification (indirect effect) & $0.14 * *$ & 0.07 & 0.39 & & \\
\hline Distributive Justice $\rightarrow$ Psychological Need Satisfaction & $.30 * *$ & .170 & 0.60 & \multirow{4}{*}{$3.02 * *$} & \multirow{4}{*}{$\mathrm{H} 5 \mathrm{~b}$} \\
\hline Psychological Need Satisfaction $\rightarrow$ Job involvement & $.65 * *$ & .31 & 1.17 & & \\
\hline Distributive Justice $\rightarrow$ Job involvement (direct effect) & -0.14 & -0.50 & 0.05 & & \\
\hline Distributive Justice $\rightarrow$ Job involvement (indirect effect) & $0.20 * *$ & 0.09 & 0.66 & & \\
\hline Interactional justice $\rightarrow$ Psychological Need Satisfaction & $.52 * *$ & .09 & 1.21 & \multirow{4}{*}{$2.18 * *$} & \multirow{4}{*}{ H6a } \\
\hline Psychological Need Satisfaction $\rightarrow$ Organisational Identification & $.47 * *$ & .23 & 0.78 & & \\
\hline Interactional justice $\rightarrow$ Organisational Identification (direct effect) & 0.18 & -0.29 & 1.02 & & \\
\hline Interactional justice $\rightarrow$ Organisational Identification (indirect effect) & $0.25^{*}$ & 0.04 & 0.75 & & \\
\hline Interactional justice $\rightarrow$ Psychological Need Satisfaction & $.52 * *$ & .09 & 1.21 & \multirow{3}{*}{$2.18 * *$} & \multirow{3}{*}{ H6b } \\
\hline Psychological Need Satisfaction $\rightarrow$ Job involvement & $.65^{* *}$ & .31 & 1.17 & & \\
\hline Interactional justice $\rightarrow$ Job involvement (direct effect) & 0.31 & -0.55 & 1.35 & & \\
\hline
\end{tabular}


Neeru Malhotra, Sunil Sahadev \& Nur Qamarina Sharom Accepted for publication in The International Journal of Human Resource Management, 14 April 2020 DOI: $10.1080 / 09585192.2020 .1757737$

Interactional justice $\rightarrow$ Job involvement (indirect effect)

$0.34 * *$

0.09

1.19

$* * p<0.00 ; * p<0.05$ 